\title{
Teoria do domínio do fato na doutrina e na jurisprudência brasileiras
}

\author{
Theory of the domain of the fact in \\ brazilian doctrine and jurisprudence
}

Pablo Rodrigo Alflen ${ }^{1}$

\section{Resumo}

O artigo analisa a teoria do domínio do fato desde o ponto de vista da doutrina nacional e da jurisprudência. Parte-se do argumento de que a doutrina pátria dispensa um tratamento absolutamente incongruente no tocante à teoria do domínio do fato, pois há muito se confunde as concepções de Welzel e de Roxin, misturando-se categorias e fundamentos dogmáticos incompatíveis entre si. Demonstra-se que tal problemática assumiu reflexo na jurisprudência e que, portanto, o julgamento da APn 470 do STF foi apenas expressão de uma práxis jurisdicional absolutamente incongruente que advém de longa data.

Palavras-chave: Domínio do fato. Domínio final do fato. Autoria, participação.

\begin{abstract}
The article analyzes the theory of the domain of the fact from the point of view of national doctrine and jurisprudence. The starting point is that the homeland doctrine dispenses an absolutely incongruous treatment regarding the theory of the domain of the fact, because it confuses, longtime, the concepts of Welzel and Roxin, mixing dogmatic categories and arguments incompatible. It is shown that this problem reflects in homeland jurisprudence and that, therefore, the judgement of APn 470 of the STF was just expression of an absolutely incongruous judicial praxis, that comes from longtime.
\end{abstract}

Keywords: Domain of the fact. Final domain of the fact. Authorship, participation.

${ }^{1}$ Professor Concursado da Faculdade de Direito da Universidade Federal do Rio Grande do Sul (UFRGS), Professor do Curso de Especialização em Direito Penal e Política Criminal da mesma instituição, Doutor e Mestre em Ciências Criminais (PUCRS), Pós-doutorando pela Georg-August-Universität Göttingen, Alemanha. 


\section{Introdução}

Os principais problemas verificados no direito penal brasileiro vigente parecem surgir justamente a partir dos déficits de interação entre teoria e prática. Um olhar mais atento permite observar que a dissonância daí resultante segue em uma via de mão dupla: de um lado, a doutrina brasileira, por vezes, funde concepções teórico-dogmáticas incompatíveis entre si, formando um mixtum compositum de coisas que não deveriam ser misturadas ${ }^{2}$; de outro lado, a práxis jurisdicional em matéria penal, de maneira autossuficiente, ou despreza construções teórico-dogmáticas na fundamentação de suas decisões ${ }^{3}$, ou, ainda, quando as utiliza, na maioria das vezes, desvirtua seu conteúdo.

No entanto, este último aspecto, qual seja, o desvirtuamento de concepções teórico-dogmáticas pela práxis jurisdicional - embora não seja uma peculiaridade brasileira $^{4}$ - é acentuado pelo fato de a doutrina penal

2 Assim, por exemplo, GRECO, Rogério. Curso de direito penl: parte geral. São Paulo: Ímpetus, 2012. v. 1. p. 422, o qual comete vários equívocos ao fundir critérios e conceitos inerentes às concepções de Welzel e Roxin, equívocos também claramente perceptíveis em BATISTA, Nilo. Concurso de agentes. 3. ed. Rio de Janeiro: Lumen Juris, 2005. p. 101; SANTOS, Juarez Cirino. A moderna teoria do fato punível. 3. ed. Curitiba: IPCP/Lumen Juris, 2004. p. 275 e s.; SANTOS, Juarez Cirino. Direito penal: parte geral. 2. ed, Curitiba: IPCP/Lumen Juris, 2007. p. 353 e s.; também PRADO, Luiz Régis. Curso de Direito penal brasileiro. 9. ed. São Paulo: Revista dos Tribunais, 2010. v. 1. p. 461; situação mais grave encontra-se em REALE JÚNIOR, Miguel. Instituições de Direito Penal: parte geral. Rio de Janeiro: Forense, 2002. v. 1 p. 315 e ss., o qual utiliza a expressão domínio do fato com o propósito de delimitar a autoria, porém, dialoga com Welzel, Roxin, Jakobs e outros, sem sequer especificar seu ponto de partida, qual seja, o que se deve entender por "domínio do fato".

3 Assim, por exemplo, reiteradas decisões do Tribunal de Justiça do Estado do Rio Grande do Sul (no que segue “TJRS”): RSE no 70011117629, julgado em 19/05/2005: "o processo não é um fim em si mesmo nem serve de palco para discussões acadêmicas"; bem como HC n 70052941077 , julgado em 20/02/2013; HC no 70057208472, julgado em 11/12/2013; HC no 70057686677, julgado em 18/12/2013; HC no 70058088691, julgado em 29/01/2014; HC n 70058394966, julgado em 26/02/2014; HC no 70058332800, julgado em 26/02/2014; disponíveis em «www.tjrs.jus.br», acesso em: 26 set. 2014.

4 Assim, por exemplo, o desvirtuamento da teoria do domínio por organização ("Organisationsherrschaft") realizado pelo próprio Bundesgerichtshof (no que segue "BGH") ao aplicá-la aos chamados crimes empresariais, cujo entendimento já foi expressamente rechaçado por ROXIN, Claus. O domínio por organização como forma independente de brasileira - salvo raras exceções ${ }^{5}$ - manifestar um déficit de identidade, pois digere concepções dogmáticas estrangeiras, muitas vezes, de forma irrefletida e apartada do seu contexto. Isso se reverte em uma certa incongruência sistêmica, facilmente identificável nos manuais; ao mesmo tempo, porém, acaba por transferir à práxis jurisdicional o difícil encargo de concretizar tais concepções teóricas, de modo que seu desvirtuamento é consequência inevitável. Exemplo paradigmático, nesse sentido, foi a decisão proferida pelo Supremo Tribunal Federal ao julgar a APn 470 - conhecida como “caso mensalão”principalmente, no que diz respeito ao concurso de pessoas ("Beteiligungslehre") e à delimitação da autoria e de suas respectivas formas (autoria direta, autoria mediata e coautoria).

Tal caso, na verdade, demonstrou o acerto das palavras de Kantorowicz ao afirmar, já em 1910, ser “a teoria da participação" (concurso de pessoas) "o capítulo mais obscuro e confuso da ciência penal (alemã)". 6 Porém, cumpre fazer uma ressalva, a de que este aspecto não fica restrito a determinado plano territorial, sendo a teoria da participação (concurso de pessoas), portanto, o capítulo mais obscuro e confuso $d a$ ciência penal. A gravidade

autoria mediata, Trad. Pablo Rodrigo Alflen, Panóptica. Law E-Journal, n 04, 2009, p. 91 e ss., disponível em «www. panoptica.org»; a respeito da posição do $\mathrm{BGH}$ compare também BRAMSEN, Joerg; APEL, Simon. Anstiftung oder Täterschaft? "Organisationsherrschaft" in Wirtschaftsunternehmen. Zeitschrift für das Juristische Studium [ZJS], $\mathrm{n}^{\circ}$ 03, 2008. p. 256; fundamental URBAN, Carolin. Mittelbare Täterschaft kraft Organisationsherrschaft. Eine Studie zu Konzeption und Anwendbarkeit, insbesondere im Hinblick auf Wirtschaftsunternehmen. 1. Aufl., Göttingen: V\&R unipress, 2004. p. 205 e ss.; RÜBENSTAHL, Markus. Die Übertragung der Grundsätze zur Tatherrschaft kraft Organisationsherrschaft auf Unternehmen durch den BGH. Höchstrichterliche Rechtsprechung zum Strafrecht [HRRS], $\mathrm{n}^{\circ}$ 10, 2003. p. 210; também ROTSCH, Thomas. Tatherrschaft kraft Organisationsherrschaft. Zeitschrift für die gesamte Strafrechtswissenschaft [ZStW], no 112, Heft 3, 2000. p. 536 e s.; ALFLEN, Pablo Rodrigo. Teoria do domínio do fato. São Paulo: Saraiva, 2014. p. 147 e ss.

5 Cite-se, por exemplo, TAVARES, Juarez. Teoria do injusto penal. 3. ed. Belo Horizonte: DelRey, 2003; bem como, em relação ao concurso de pessoas e a teoria do domínio do fato: MIRABETE, Julio Fabbrini. Manual de Direito Penal. Parte Geral. 21. ed. São Paulo: Atlas, 2004. p. 229 e ss., o qual, apesar de mencionar sucintamente a teoria, segue uma posição coerente; DOTTI, René Ariel. O concurso de pessoas. Revista da Faculdade de Direito da UFG, n. 5 (1-2), jan./dez., 1981, p. 77 e ss.

6 Cfe. KANTOROWICZ, Hermann. Der Strafgesetzentwurf und die Wissenschaft. Monatsschrift für Kriminalpsychologie und Strafrechtsreform, Bd. 7, 1911. p. 257-344. 
dos equívocos cometidos ao longo da decisão proferida no "caso mensalão", especialmente no que diz respeito à teoria do domínio do fato, não é mais do que expressão de uma práxis incongruente que advém de longa data. Para compreender tal problemática, realizar-se-á, em primeiro lugar, uma breve análise do emprego da teoria do domínio do fato como critério de delimitação da autoria, desde o ponto de vista da doutrina e da jurisprudência brasileiras, com a finalidade de demonstrar alguns dos principais equívocos cometidos. Em segundo lugar, identificar-se-ão alguns dos principais argumentos sustentados pelo Supremo Tribunal Federal ao empregar a teoria do domínio do fato no famigerado "caso mensalão" e as principais incongruências evidenciadas. Por fim, analisar-se-ão alguns aspectos atinentes à (in)compatibilidade da teoria do domínio do fato, em especial a de Roxin, com a ordem jurídico-penal brasileira.

\section{Domínio do fato na perspectiva brasileira}

\subsection{A doutrina}

As expressões "domínio do fato" e "domínio sobre o fato", como se tem conhecimento a partir dos trabalhos de Schroeder e de Roxin, foram empregadas pela primeira vez no direito penal alemão por Hegler, em 1915, no trabalho intitulado "Die Merkmale des Verbreches". Após isso, verifica-se o emprego da expressão "domínio do fato" por Goldschmidt, no trabalho "Normativer Schuldbegriff", de 1930 (no mesmo sentido de Hegler) e por Frank, em seu "Das Strafgesetzbuch für das Deutsche Reich", de 1931 (18 . edição), seguido por Bruns, no trabalho intitulado "Kritik der Lehre vom Tabestand", de 1932; por Lobe, em sua "Einführung in den Allgemeinen Teil des Strafgesetzbuch", de 1933; por Berges, no trabalho intitulado "Der gegenwärtige Stand der Lehre vom dolosen Werkzeug in Wissenschaft und Rechtsprechung", de 1934; por H. von Weber, no trabalho intitulado "Zum Aufbau des Strafrechtssystems", de 1935, e por Eb. Schmidt, no trabalho intitulado “Die militärische Straftat und ihr Täter", de 1936.7

Cfe. ROXIN, Claus. Täterschaft und Tatherrschaft. p. 63, fazendo referência ao trabalho de von Weber intitulado "Zum Aufbau des Strafrechtssystems", de 1935; ademais, SCHROEDER, Fr.-Christian. Täter hinter dem Täter. p. 61, o qual menciona, além deste trabalho de von Weber citado por Roxin, o artigo intitulado "Die garantierende Funktion der Strafgesetze”, DJZ, 1931, p. 663 e ss.; veja ainda HAAS, Volker. Die Theorie der Tatherrschaft und ihre Grundlagen.
Todavia, como adverte Roxin, "os pontos de partida dogmáticos que levaram ao desenvolvimento da ideia de domínio do fato são muito diferentes"8, daí a dificuldade em se proporcionar um histórico dogmático de tal teoria, de modo que seu avanço em direção a uma concepção predominante acaba por se reportar necessariamente a Welzel. $^{9}$

Apesar de Welzel ter apresentado, em 1939, pela primeira vez, uma teoria do domínio do fato propriamente dita, como critério de delimitação da autoria ${ }^{10}$, não há dúvida de que os maiores esforços e a maior construção edificada até então, a respeito da temática, partiram de Roxin, o qual levou sua concepção a público no ano de $1963^{11}$. O ponto de partida de Roxin na elaboração de sua

Zur Notwendigkeit einer Revision der Beteiligungslehre. 1. Aufl., Berlin: Duncker \& Humblot, 2008. p. 15; em sentido semelhante SCHILD, Wolfgang. Tatherrschaftslehren. p. 9 e s., o qual refere que a teoria do domínio do fato foi fundada por Welzel, mas teve seus princípios em Hegler (1915), Frank e Goldschmidt (1931), Bruns (1932), H. v. Weber (1935), Eb. Schmidt (1936) e Lobe (1933); compare, ainda, ALFLEN, Pablo Rodrigo. Teoria do Domínio do Fato. $1^{\text {a }}$. ed., São Paulo: Saraiva, 2014. p. 80 e ss.

8 Cfe. ROXIN, Claus. Täterschaft und Tatherrschaft. p. 64; para um exame aprofundado disso, compare ALFLEN, Pablo Rodrigo. Teoria do domínio do fato. p. 81 e ss.

9 Cfe. ROXIN, Claus. Täterschaft und Tatherrschaft. p. 64; tal argumento procede, uma vez que a doutrina, de modo geral, ao se reportar à teoria do domínio do fato aponta Welzel como seu precursor; compare, nesse sentido, HAAS, Volker. Die Theorie der Tatherrschaft und ihre Grundlagen. p. 15. Portanto, é incorreta a afirmação de Greco e Leite (In: GRECO, Luís et al. Autoria como domínio do fato. São Paulo: Marcial Pons, 2014, p. 21-2), de que "apenas em 1963, com o estudo monográfico de Roxin, a ideia teve os seus contornos concretamente desenhados", pois a mesma já havia sido suficientemente delineada em Welzel à luz de sua concepção de ação finalista, sendo que o próprio Roxin admite isso, quando afirma que "no ano de 1939, finalmente, surge o conceito de domínio do fato em Welzel. Ele foi o primeiro a colocar a ideia de domínio do fato em vinculação com a teoria da ação e extrai disso uma "autoria final", cujo critério ele encontra no domínio do fato", ROXIN, Claus. Täterschaft und Tatherrschaft. p. 64.

10 WELZEL, Hans. Studien zum System des Strafrechts, In: Abhandlungen zum Strafrecht und zur Rechtsphilosophie, Berlin: Walter de Gruyter, 1975. p. 161 e ss. (publicado originariamente in ZStW, Bd, 58, 1939).

11 Compare a tese de habilitação do autor, publicada em sua primeira edição no ano de 1963: ROXIN, Claus. Täterschaft und Tatherrschaft. p. 25 e ss.; bem como ROXIN, Claus. Straftaten im Rahmen organisatorischer Machtapparate. GA, 1963. p. 192 e ss.; também ROXIN, Claus. Strafrecht, AT. Bd. II, München: Beck, 2003. p. 9 e ss.; ROXIN, Claus. Organisationsherrschaft und Tatentschlossenheit. ZIS, nº 07, 2006, p. 293 e ss.; ademais ROXIN, Claus. $O$ domínio por organização como forma independente de autoria mediata. p. 69 e ss. 
teoria foi a singular vagueza e a intangibilidade da concepção welzeliana, que o levaram a rechaçar a ideia de domínio do fato finalista. Inclusive, em sua crítica, Roxin foi categórico ao esclarecer, de um lado, que Welzel introduziu o conceito "de forma absolutamente repentina e sem explicação, como se seu significado fosse compreensível por si mesmo"12 e, de outro lado, que a "unilateralidade dos critérios compreendidos de forma lógica e exata" e a "sua incapacidade de satisfazer as diversas formas de manifestação da vida em suas expressões individuais" não servem como critérios para definir a ideia de domínio do fato. ${ }^{13}$

Embora na doutrina alemã o debate acerca desta teoria tenha prosseguido de forma latente e profunda - a ponto de Schild demonstrar a existência de diversas variantes na atualidade ${ }^{14}$ - a ideia de domínio do fato somente adentrou no plano teórico-dogmático brasileiro no ano de 1979 e ficou restrita às concepções de Welzel e Roxin. O mérito imperecível de Nilo Batista em trazer a teoria para o Brasil, na sua clássica obra Concurso de Agentes, já na primeira edição, no entanto, não impede a crítica no sentido de o jurista brasileiro não ter deixado claro o limite e as diferenças entre estas duas concepções ${ }^{15}$. Tal esclarecimento, naquela ocasião, era imprescindível, quer seja por se tratar de uma nova concepção a adentrar o cenário teórico-dogmático brasileiro, quer seja por não haver ponto de confluência entre ambas as teorias. Por conseguinte, tanto o desenvolvimento histórico-dogmático da ideia de domínio do fato, quanto o estudo pormenorizado da teoria e de seus respectivos critérios, por muito tempo, permaneceram distantes dos trabalhos científicos brasileiros. Tais trabalhos se limitavam a abordar ou a concepção de Welzel ou a de Roxin, ou, ainda, as duas

12 Cfe. ROXIN, Claus. Täterschaft und Tatherrschaft. p. 109.

13 Cfe. ROXIN, Claus. Täterschaft und Tatherrschaft. p. 112.

14 Cfe. SCHILD, Wolfgang. Tatherrschaftslehren. p. 33, o qual refere, além das teorias de Welzel, Maurach, Gallas e Roxin, as variantes desenvolvidas por Schünemann, Bottke, Jakobs, Murmann/Bolowich/Noltenius, Renzikowski, Heinrich, Schneider, Otto, Buse/Schwab, Gropp/Ransiek/ Schild/Schlösser, Sinn/Lampe, Schmidhäuser, Luzón Pena/ Diaz y Carcia, Jescheck/Rogall/Rudolphi, sendo que a estas acrescentamos nossa concepção em ALFLEN, Pablo Rodrigo. Teoria do domínio do fato. p. 184 e ss.

15 Observe-se que, antes de Batista, encontra-se na doutrina brasileira uma brevíssima menção à ideia de "domínio sobre o fato", no sentido de Welzel, em BRUNO, Anibal. Direito Penal. PG. Rio de Janeiro: Forense, v. 1, tomo $2^{\circ}$, 1956, p. 266, nota de rodapé 7 conjuntamente (daí o referido "mixtum compositum"), porém, ainda assim, elaborando um exame superficial, confuso e acrítico das teorias. ${ }^{16}$ Naturalmente, a inexistência de qualquer estudo posterior a respeito da teoria do domínio do fato, em caráter aprofundado, no Brasil, permitiu que a mesma fosse propalada em meio à doutrina e à jurisprudência de forma obscura e equivocada. Entretanto, simplesmente depositar a teoria de Roxin no âmbito brasileiro, sem sequer estabelecer as diferenças teóricas desta para com a de Welzel, e, pior, sustentar que somente em Roxin surgiu uma teoria do domínio do fato - como o fazem atualmente Greco e Leite - é no mínimo algo leviano e anticientífico ${ }^{17}$.

16 Com brevíssima e lacunosa referência histórica, veja BATISTA, Nilo. Concurso de agentes. p. X; sem qualquer referência histórica e com análise absolutamente superficial da teoria, compare o opúsculo de JESUS, Damásio de. Teoria do domínio do fato no concurso de pessoas. 3. ed., São Paulo: Saraiva, 2002. p. 17 e ss., no qual o autor sequer procura analisar o que se entende ou deve entender por "domínio do fato" e limita-se a referir que aderiu à teoria do domínio do fato de Welzel.

17 Devido à cega e acrítica adesão às teorias roxinianas e no afã de proceder ao seu "depósito" no âmbito brasileiro, em trabalho recentemente publicado, Greco e Leite deturparam a teoria de Welzel ao afirmar que este teria tão só reproduzido a concepção de Lobe e a denominado de domínio final do fato. Como é sabido, Welzel elaborou uma concepção original e muito coerente com o seu próprio sistema finalista e, portanto, tal afirmação é leviana, uma vez que um simples exame comparativo entre as obras de Lobe e de Welzel evidencia as diferenças entre as concepções. Além disso, em uma singela exposição histórico-dogmática da teoria do domínio do fato, Greco e Leite "esquecem" de mencionar as figuras de Goldschmidt, Frank e Bruns, os quais fizeram referência à expressão "domínio do fato" ou "domínio sobre o fato". E mais, sequer mencionam que, após Lobe, também Berges , H. von Weber e Eb. Schmidt fizeram menção à expressão "domínio do fato", sobretudo os dois últimos, os quais efetivamente a vincularam à ideia de autoria. Com isso, acabaram por não apresentar - embora tenham se proposto a fazê-lo - a origem da teoria, mas sim um recorte histórico leviano e muito precário do seu desenvolvimento, um esdrúxulo esboço daquilo que, a seu juízo, consideram pertinente que o (menosprezado) leitor brasileiro saiba. Mas a situação se agrava mais ainda, pois, partindo da ideia de que o leitor brasileiro não tem ou não terá acesso à bibliografia alemã, Greco e Leite inventam o que não existe e desvirtuam o pensamento de colegas alemães, não muito conhecidos do público brasileiro. Assim, por exemplo, afirmam que Thomas Rotsch propõe "um retorno ao conceito extensivo de autor", quando o jurista alemão jamais o fez . Muito longe disso, Rotsch propõe a total dissolução das categorias de autoria e participação (isto é, a supressão das próprias expressões "autoria" e "participação”), posto que, na sua visão, são obsoletas, mas, de forma alguma, propõe um retorno ao conceito extensivo (o qual 
É fundamental ter em vista que a teoria de Roxin não consistiu em um simples aprimoramento da concepção de Welzel, mas, sim, em uma construção absolutamente nova e original, de modo que a doutrina brasileira deveria ter se preocupado em identificar sistematicamente as diferenciações teóricas e práticas de ambas as teorias. Isso permitiria concluir que se tratam de teorias diferentes alicerçadas em sistemas diversos e que, portanto, a adesão a um dos sistemas subjacentes conduziria à adoção da respectiva vertente teórica (evitando-se, assim, o inconcebível mixtum compositum). Ademais, forneceria o subsídio necessário para optar por uma ou outra vertente e, por conseguinte, aplicá-la adequadamente no plano jurisdicional.

As principais diferenças dogmáticas entre as teorias podem ser sintetizadas levando-se em consideração os seguintes aspectos:

a) Welzel entende que a autoria depende de dois pressupostos, a saber: 1) pressupostos pessoais, os quais decorrem da estrutura do tipo e se subdividem em 1.1) objetivos, tais como a posição especial de dever do autor (funcionário público, militar, comerciante, mãe, médico, advogado, etc.), e 1.2) subjetivos, tais como intenções especiais, tendências ou tipos de sentimentos (os chamados elementos subjetivos do injusto); e 2) pressuposto fático: o domínio final do fato (o autor é o senhor sobre a decisão e sobre a execução da sua vontade final ${ }^{18}$. Logo, para o penalista alemão, o "domínio final do fato" (“finale Tather-

não supõe a extirpação daquelas expressões), para isso remeta-se o leitor à ROTSCH, Thomas. 'Einheitstäterschaft' statt Tatherrschaft. Tübingen: Mohr Siebeck, 2009, p. 421 e ss. Inclusive, um simples exame do recente trabalho publicado pelos pupilos brasileiros de Roxin, possibilitará ao leitor observar que o livro consiste em um esboço resumido do trabalho do jurista alemão, aliás, não se poderia esperar algo diferente de um trabalho escrito a oito mãos, em que se constata uma nítida ruptura no pensamento, permitindo concluir que a participação de um dos autores em quase todos os textos tem o fito de querer induzir uma suposta conexão de ideias, todavia, inexistente, compare GRECO, Luis et al. Autoria como domínio do fato. São Paulo: Marcial Pons, 2014. p. 21 e ss.

18 Cfe. WELZEL, Hans. Studien zum System des Strafrechts. Berlin: Walter de Gruyter, 1975. p. 164; ademais WELZEL, Hans. Das Deutsche Strafrecht: Eine systematische Darstellung. 11. Aufl., Berlin: Walter de Gruyter, 1969. p. 82 a 84: "senhor sobre o fato é quem o realiza finalisticamente com base na sua decisão de vontade". Inclusive, este é o fundamento pelo qual Bockelmann, que adere ao domínio do fato finalista, ressalta que o "domínio final do fato é uma característica da autoria”, compare BOCKELMANN, Paul. Strafrechtliche Untersuchungen. Göttingen: Verlag Otto Schwartz \& Co, 1957. p. 52. rschaft") não é o único critério para determinar a autoria, mas tão só o seu pressuposto material. ${ }^{19}$

Roxin, no entanto, desenvolve a ideia de domínio do fato sob o argumento de que "o autor é a figura central ("Zentralgestalt"), a figura chave ("Schlüsselfigur") do acontecimento mediado pela conduta" ${ }^{20}$, o autor é sempre "a figura central de um acontecimento executório" ("Ausführungsgeschehen"), isto é, "a figura central da conduta executória" ("Ausführungshandlung")21 e que a "figura central do processo delitivo é quem domina o acontecimento dirigido à realização do delito"22. Daí referir ser autor aquele "que domina o fato, isto é, que desempenha o papel decisivo na realização do tipo" ${ }^{23}$, de modo que "tem o domínio do fato e é autor, quem aparece como a figura central, a figura chave na realização do delito, por meio de sua influência decisiva para o acontecimento" ${ }^{24}$. Com isso, tem-se que autor direto é aquele que realiza, pela própria pessoa, todos os elementos de um tipo penal. E, portanto, diferentemente de Welzel, para Roxin, o domínio do fato é critério suficiente para determinar a autoria, porém, exclusivamente em relação ao crimes comissivos dolosos, uma vez que não se aplica aos chamados delitos de violação de dever, aos delitos de mão própria e aos delitos culposos (os quais são regidos por critérios distintos).

b) Welzel reconhece as três modalidades de autoria, a saber: a autoria direta, a autoria mediata e a coautoria. Porém, por entender que o conceito de domínio do fato é um pressuposto fático da autoria, não faz diferenciação entre espécies ou formas de domínio do fato.

Roxin, diferentemente, desenvolve um modelo tripartido de domínio do fato, distinguindo entre as formas de domínio da ação, domínio funcional e domínio da

19 Cfe. SCHROEDER, Fr.-Christian. Der Täter hinter dem Täter. p. 63, o qual refere que "o domínio do fato é um momento complementar, que se apresenta no âmbito do concurso de pessoas junto ao conceito de ação"; ainda HAAS, Volker. Die Theorie der Tatherrschaft und ihre Grundlagen, p. 15.

20 ROXIN, Claus. Täterschaft und Tatherrschaft. p. 25, 108 e 527; uma análise sintética e crítica desta diretriz roxiniana em SCHILD, Wolfgang. Täterschaft als Tatherrschaft. p. 6 e ss.

21 ROXIN, Claus. Strafrecht, AT, Bd. II. p. 9.

22 ROXIN, Claus. Strafrecht, AT, Bd. II. p. 10; igualmente ROXIN, Claus. Täterschaft und Tatherrschaft. p. 527: "a figura central é caracterizada pelos elementos do domínio do fato, da violação de um dever especial ou pelas próprias mãos".

23 ROXIN, Claus. Strafrecht, AT, Bd. II. p. 11.

24 ROXIN, Claus. Strafrecht, AT, Bd. II. p. 14. 
vontade, os quais correspondem, respectivamente, à autoria direta, à coautoria e à autoria mediata. ${ }^{25}$

c) Para Welzel, "a melhor representação visual" da coautoria "é a da divisão de papeis ('Rollenverteilung') em um plano elaborado conjuntamente"26, ou, ainda, a divisão de trabalho ("Arbeitsteilung") 27, sendo a "decisão conjunta" e a "execução conjunta" do fato seus requisitos imprescindíveis. Esclarece, contudo, que o coautor não possui o poder de decisão sobre a realização do fato integral, mas tão só sobre a sua parcela de contribuição.

Embora Roxin pareça coincidir com Welzel, quando afirma que a coautoria ocorre com a "realização do tipo por meio da execução pela divisão de trabalhos ("arbeitsteilige Ausführung")"28, de forma absolutamente diversa estabelece três pressupostos para a coautoria, a saber ${ }^{29}: 1$ ) a existência de um planejamento conjunto do fato; 2) a execução conjunta do fato, "não sendo suficiente uma participação na preparação" (diferentemente de Welzel, para quem a contribuição do coautor pode consistir em ato preparatório e de apoio $^{30}$ ); 3) a prática de uma contribuição essencial à etapa da execução ${ }^{31}$.

25 ROXIN, Claus. Täterschaft und Tatherrschaft. p. 527: "o domínio do fato, que nos delitos comissivos dolosos determina o conceito geral de autor, ocorre nas formas de manifestação do domínio da ação, do domínio da vontade e do domínio do fato funcional"; refere também que "com o propósito de preencher este conceito da espécie de cláusula geral e, antes de tudo, formal com conteúdo, nós encontramos os critérios do domínio da ação, do domínio da vontade e do domínio do fato funcional, que se apresentam todos os três como formas de um princípio mais abrangente do domínio do fato" (p. 335); veja a respeito, também, AMBOS, Kai. Tatherrschaft durch Willensherrschaft kraft organisatorischer Machtapparate. GA,1998, p. 226: "Roxin distingue três formas de domínio do fato (domínio do fato pela ação, pela vontade e funcional)...”; também SCHILD, Wolfgang. Täterschaft als Tatherrschaft. p. 7.

26 WELZEL, Hans. Studien zum System des Strafrechts. p. 171.

27 WELZEL, Hans. Das Deutsche Strafrecht. Berlin: Walter de Gruyter, 1989. p. 107.

28 ROXIN, Claus. Strafrecht, AT, Bd. II. p. 77.

29 ROXIN, Claus. Strafrecht, AT, Bd. II. p. 78.

30 WELZEL, Hans. Das Deutsche Strafrecht. p. 90; em sentido semelhante, na doutrina alemã contemporânea, compare KINDHÄUSER, Urs. Strafrecht. AT. 2. Aufl., Baden-Baden: Nomos Verlag, 2002. p. 400-401, o qual afirma que, segundo o entendimento predominante, é suficiente a colaboração na etapa de preparação quando esta possui significado decisivo para o decurso posterior e o êxito do fato, sendo que só para a teoria do domínio do fato é necessária a colaboração direta na realização do fato; no mesmo sentido refere OTTO, Harro. Grundkurs Strafrecht. Allgemeine Strafrechtslehre. 7. Aufl., Berlin: Walter de Gruyter, 2004. p. 268. d) Para Welzel, a autoria mediata consubstancia-se na ideia do domínio final do fato por parte daquele que está por trás do instrumento (Werkzeug), sendo que esse último, em hipótese alguma, pode possuir o domínio pleno do fato, caso contrário, aquele que está por trás será mero indutor ou instigador. ${ }^{32}$ "Para a autoria mediata, de modo algum é exigível que o autor se sirva de um instrumento mecânico realmente eficaz", visto que "ele pode adaptar em certa extensão a conduta final de outrem à sua atividade final, desde que conserve - ao contrário do outro - o pleno domínio do fato sobre o fato integral"33. Com isso, deixa claro que a autoria mediata pode se dar no caso de o instrumento ser um indivíduo que atua de maneira consciente ou inconscientemente final, tanto $p u$ nível quanto impunível, e desde que o autor mediato tenha o domínio integral do fato.

Roxin, por seu turno, considera que a autoria mediata ocorre quando um indivíduo se serve de outro (um “intermediador") para atingir seus fins, de tal modo que, por meio da instrumentalização deste (isto é, de seu uso como "instrumento"), aquele domina o acontecimento de forma mediata (como "homem de trás"). ${ }^{34}$ Assim, esclarece que, enquanto no domínio da ação a realização da conduta típica pelas próprias mãos fundamenta a autoria, na autoria mediata falta justamente uma conduta executória por parte do homem de trás, de maneira que o domínio do fato somente pode se basear no "poder de conduzir a vontade", e isso, aliás, só se pode imaginar no caso de uso de um indivíduo que "não atua livremente" 35 , o qual, ao contrário do preconizado por Welzel, é um sujeito impunível (embora, mais recentemente, Roxin tenha modificado sua concepção no tocante ao domínio do fato pelo domínio da vontade em virtude de aparatos

Werner. Strafrecht. AT. Die Straftat und ihr Aufbau. 35. Aufl., Heidelberg: C.F.Müller Verlag, 2005. p. 191-192, os quais afirmam que para o êxito do fato é exigido de qualquer coautor uma colaboração essencial na etapa de execução ("wesentliche Mitwirkung im Ausführungsstadium"). Este aspecto tem sido muito discutido na dogmática jurídico-penal, sendo que Roxin tem plena consciência disso, compare ROXIN, Claus. Täterschaft und Tatherrschaft. p. 657, referindo que "o ponto de diferenciação material decisivo no momento radica na questão se [...] basta para a fundamentação da coautoria uma participação na etapa da preparação ou se, para isso, é exigível uma colaboração complementar à contribuição de outrem na própria execução".

32 WELZEL, Hans. Studien zum System des Strafrechts. p. 165. 33 WELZEL, Hans. Studien zum System des Strafrechts. p. 164.

34 ROXIN, Claus. Strafrecht, AT, Bd. II. p. 22.

35 ROXIN, Claus. Täterschaft und Tatherrschaft. p. 142. 
organizados de poder, admitindo, assim, um instrumento punível fungível).

O esclarecimento de tais diferenças, por ora, já são suficientes para identificar os principais equívocos cometidos pela doutrina brasileira. Assim, por exemplo, Batista comete inúmeras falhas, pois designa a teoria do domínio do fato de "critério... final-objetivo" e afirma ter sido "elaborada por Welzel, e mais tarde por Gallas e Maurach", sendo que, atualmente, "conta com o endosso, entre outros, de Roxin..." ${ }^{36}$. Ora, Roxin, por sua vez, afirmou ser sua teoria construída a partir do rechaço à concepção finalista, de modo que Batista estava incorreto ao afirmar que houve "endosso" por parte de Roxin à teoria do domínio fato finalista. Porém, tratar-se-ia de uma crítica limitada, sobretudo, em face de equívocos maiores cometidos pelo jurista brasileiro. Nesse sentido, refere Batista que "é autor direto aquele que tem o... domínio da ação... pela pessoal e dolosa realização da conduta típica”. Ao fazer referência ao domínio da ação o jurista brasileiro se reporta à categoria desenvolvida por Roxin, porém, prossegue afirmando que "o domínio do fato (na forma de domínio da ação) é apenas o elemento geral do autor..., ao qual se deverão agregar, como ensina Welzel, os elementos especiais da autoria" ${ }^{37}$. Evidentemente, trata-se de uma confusão inaceitável, uma vez que o jurista brasileiro funde duas concepções que não podem ser fundidas. Como já referido, para Roxin, o domínio do fato é critério suficiente para determinar a autoria (frise-se, nos crimes comissivos dolosos) enquanto, para Welzel, é critério complementar. Ademais, a classificação "domínio da ação" não integra a concepção de Welzel, mas sim a de Roxin.

A incongruência, no entanto, é acentuada a partir da análise elaborada por Batista acerca da coautoria, pois afirma que o "fundamento dessa (co-) autoria reside também no domínio do fato, especializado agora naquilo que Roxin chamou de domínio funcional do fato" e ressalta que "a co-autoria se sujeita a duas exigências: a comum resolução para o fato e a comum (sob divisão de traba-

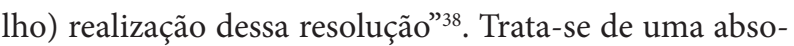
luta contradição, pois - como já referido anteriormente - estes dois últimos critérios foram delineados por Welzel, o qual jamais fez menção à categoria jurídico-penal

BATISTA, Nilo. Concurso de agentes. p. 69-70. BATISTA, Nilo. Concurso de agentes. p. 77.

8 BATISTA, Nilo. Concurso de agentes. p. 102. do domínio funcional. Roxin, diferentemente de Welzel, estabelece três pressupostos para a coautoria, a saber: 1) a existência de um planejamento conjunto do fato; 2) a execução conjunta do fato, "não sendo suficiente uma participação na preparação"; 3) a prática de uma contribuição essencial à etapa da execução ${ }^{39}$. Portanto, mais uma vez o jurista brasileiro funde as duas concepções sem sequer perceber que apresentam critérios diversos e, portanto, não podem ser misturadas.

Em sentido semelhante cumpre destacar a confusão causada por Cirino dos Santos, o qual afirma ter sido a teoria do domínio do fato "desenvolvida essencialmente por Roxin - embora, anteriormente, Welzel tivesse falado em domínio final do fato" ${ }^{30}$. O equívoco na afirmação está em que Welzel não apenas "falou" em domínio final do fato, pois o jurista alemão criou, de forma absolutamente original e coerente, a primeira teoria propriamente dita do domínio do fato, sendo que isto foi reconhecido não só pelo próprio Roxin como pela doutrina alemã em geral. ${ }^{41}$ Além disso, ao abordar a coautoria, Cirino dos Santos refere que "a realização comum do fato é constituída pelas contribuições objetivas de cada co-autor para o acontecimento total, que explicam o domínio funcional do tipo de injusto". Trata-se de afirmação absolutamente equivocada, pois - assim como Batista - Cirino dos Santos emprega o critério desenvolvido por Welzel, da realização comum ("gemeinsame Tatausführung")" , e o vincula ao conceito de domínio funcional do fato ("funktionelle Tatherrschaft"), o qual é categoria jurídica criada por Roxin e absolutamente estranha à teoria de Welzel. ${ }^{43}$

O mesmo equívoco de Cirino dos Santos é cometido por Greco, o qual, apesar de deixar claro ter tomado como diretriz a teoria welzeliana, faz referência à ideia

ROXIN, Claus. Täterschaft und Tatherrschaft. p. 657.

40 SANTOS, Juarez Cirino dos. A moderna teoria do fato punivel. p. 275 e s.; SANTOS, Juarez Cirino. Direito Penal, PG. p. 353 e s.

${ }^{41}$ ROXIN, Claus. Täterschaft und Tatherrschaft. p. 64: "é difícil oferecer, afinal, um desenvolvimento histórico dogmático a teoria do domínio do fato. Seu avanço em direção a uma concepção predominante remonta, sem dúvida, a Welzel", e prossegue afirmando que "somente Welzel conferiu eficácia a esta teoria e finalmente ajudou a implementá-la"; compare, ainda, por todos Schild, Tatherrschaftslehren, p. 9: "a teoria do domínio do fato... foi fundada por Hans Welzel em 1939".

42 WELZEL, Hans. Das Deutsche Strafrecht. p. 108-109.

43 ROXIN, Claus. Täterschaft und Tatherrschaft. p. 275 e ss. 
de "domínio funcional do fato" ${ }^{4}$, sendo que esta forma de domínio jamais foi referida por Welzel (como dito, trata-se de categoria jurídica própria da concepção de Roxin e estranha à de Welzel). Logo, tanto Batista quanto Cirino dos Santos e Greco (ao lado dos quais podem ser inseridos, também, Bitencourt, Galvão e Mayrink da Costa ${ }^{45}$ ), de forma inconcebível, misturam ambas as teorias. Todavia, os equívocos de Greco não ficam restritos a este aspecto, pois afirma, ainda, que "a teoria do domínio do fato é considerada objetivo-subjetiva", o que, desde o ponto de vista adotado (ressalte-se, Greco parte da teoria do domínio final do fato) é incorreto, pois Welzel não considera o domínio do fato como dotado de aspecto objetivo-subjetivo, mas sim como pressuposto fático (material) da autoria ${ }^{46}$.

Incongruência maior parece cometer Régis Prado, o qual, apesar de declarado finalista, mistura na integralidade as concepções de Welzel, Maurach e Roxin, sendo oportuno transcrever sua afirmação, devido à gravidade dos equívocos:

c) Teoria do domínio do fato, objetiva final ou objetiva-subjetiva de base finalista (Welzel, Maurach), conceitua autor como aquele que tem o domínio final do fato (conceito

44 GRECO, Rogério. Curso de Direito Penal. vol. I. p. 422 e 424: "se autor é aquele que possui o domínio do fato, é o senhor de suas decisões, coautores serão aqueles que tem o domínio funcional dos fatos", o mesmo absurdo verifica-se em GRECO, Rogério. Código Penal Comentado. 8. ed. São Paulo: Ímpetus, 2014. p. 100, onde refere que autor "é o senhor de suas decisões", afirmando, ainda, que "pode-se entretanto afirmar com Roxin que cada coautor tem a sorte do fato total em suas mãos" e, logo após, "na lapidar lição de Welzel, 'a coautoria é autoria; sua particularidade consiste em que o domínio do fato unitário é comum a várias pessoas".

45 Compare BITENCOURT, Cezar Roberto. Tratado de Direito Penal: parte geral. 16. ed. São Paulo: Saraiva, 2011, v. 1. p. 488 - 489; GALVÃO, Fernando. Direito Penal: parte geral. Rio de Janeiro: Ímpetus, 2004. p. 440 e 442, o qual faz referência à teoria do domínio final do fato, de Welzel, porém, logo após, prossegue citando as formas de domínio criadas por Roxin (domínio funcional e domínio da vontade); COSTA, Álvaro Mayrink. Direito Penal: parte geral. 8. ed., Rio de Janeiro: Forense, 2009. v. 2 p. 1637, o qual refere, ainda, de forma errônea, que: "este é o objetivo da doutrina do domínio final do fato que, iniciada por Löbe, foi impulsionada por Roxin". De forma absolutamente confusa no tocante ao concurso de pessoas: BRANDÃO, Cláudio. Curso de Direito Penal. PG. Rio de Janeiro: Forense, 2008, p. 271; CAPEZ, Fernando. Curso de Direito Penal: parte geral. 12. ed. São Paulo: Saraiva, 2008. p. 337, os quais sequer observam a distinção entre os conceitos extensivo e restritivo e as teorias objetivas e subjetiva e do domínio do fato, colocando-as, todas, no mesmo nível teórico. regulativo), enquanto o partícipe carece desse domínio.

O princípio do domínio do fato significa que o 'autor final é senhor e dono de sua decisão e execução [...]. Vale dizer: 'tomar nas mãos o decorrer do acontecimento típico compreendido pelo dolo'. Pode ele se expressar em domínio da vontade (autor direto e mediato) e domínio funcional do fato (coautor). ${ }^{47}$

O equívoco da afirmação causa perplexidade. Por um lado, Régis Prado cria uma "colcha de retalhos" (um típico “Frankenstein”), pois funde as concepções de Welzel (“domínio final do fato"), Maurach (“tomar nas mãos o decorrer do acontecimento típico compreendido pelo dolo”) e Roxin (“domínio da vontade... e domínio funcional...”), o que é teórica e metodologicamente inadmissível, sobretudo, porque tais concepções são absolutamente distintas, incompatíveis entre si e, na maioria dos casos, conduzem a resultados distintos ${ }^{48}$. Por outro lado, o jurista pátrio afirma que a ideia de "domínio da vontade" expressa a autoria direta e mediata, de modo que isso deixa claro que Régis Prado desconhece a tripartição elaborada por Roxin entre domínio da ação (autoria direta), domínio da vontade (autoria mediata) e domínio funcional (coautoria) ${ }^{49}$.

Por sua vez, Queiroz afirma ter sido a teoria do domínio do fato impulsionada por Welzel e Roxin, porém, deixa obscurecida sua posição em relação a uma dessas concepções. Em meio a essa obscuridade, o jurista brasileiro igualmente comete graves equívocos, pois afirma que "a coautoria é, pois, uma forma de autoria, cuja peculiaridade consiste em que o domínio do fato unitário é comum a várias pessoas e, diferentemente da participação, em que o partícipe atua com animus socii, ou seja, quer o fato como alheio, o coautor atua com animus auctoris, isto é, ele quer o fato como próprio, de sorte que a diferença decisiva entre um e outro reside no âmbito subjetivo" 50 . A incongruência da afirmação de Queiroz surpreende, pois funde a ideia por ele referida de "domínio do fato unitário" (?) com os critérios da obsoleta teoria

PRADO, Luiz Régis. Curso de direito penal brasileiro. 9. ed. São Paulo: Revista dos Tribunais, 2010. v. 1, p. 461.

48 ALFLEN, Pablo Rodrigo. Teoria do domínio do fato. p. 96 e s. 49 ALFLEN, Pablo Rodrigo. Teoria do domínio do fato. p. 111 e s. 50 QUEIROZ, Paulo. Direito penal: parte geral, p. 291, surpreende, inclusive, o fato de o jurista brasileira utilizar como fonte desta afirmação (em nota rodapé) a figura de Welzel, quando o jurista alemão rechaçou a teoria subjetiva, criticou veementemente os conceitos de animus socii e animus auctoris, e jamais em sua vasta obra (entre artigos e livros) afirmou o que é afirmado por Queiroz. 
subjetiva (animus auctoris e animus socii), de Köstlin e Buri, a qual havia sido adotada pelo Tribunal do Reich, difundida por Kohlrausch e Lange, e veementemente combatida por Welzel ${ }^{51}$. Não há como vincular os critérios da teoria subjetiva (animus auctoris e animus socii) com a teoria do domínio [final] fato, e isso, inclusive, sequer foi feito por Welzel ou por Roxin.

Como não poderia ser diferente, as incongruências e as contradições da doutrina brasileira e, portanto, a falta de um referencial teórico-dogmático coerente a evidenciar as nítidas diferenciações entre ambas as concepções, naturalmente, dificultaram aos tribunais brasileiros a utilização da teoria do domínio do fato como diretriz para delimitação da autoria e de suas respectivas modalidades (autoria imediata, mediata e coautoria). A consequência disso radica em que, assim como ocorre com o BGH alemão, de um lado, não se encontra homogeneidade nos critérios utilizados pelos tribunais brasileiros, e, de outro lado, é evidenciada certa incongruência na utilização dos próprios critérios dogmáticos estabelecidos, seja por Welzel, seja por Roxin, e isso, inegavelmente, dificulta a controlabilidade dos atos jurisdicionais.

Ademais, na diferenciação entre as modalidades clássicas de autoria (imediata, mediata e coautoria), verifica-se a utilização, por parte dos tribunais nacionais, de ideias de domínio do fato, mas não necessariamente de uma teoria uníssona e coerente como fundamento de suas decisões, que possibilite caracterizar a autoria de forma legítima. Com isso se quer dizer que, algumas vezes, é apenas mencionada a expressão domínio do fato sem ser apresentada uma fundamentação da autoria com base em critérios que informem quando o indivíduo detém tal domínio e, outras vezes, assim como ocorre na doutrina, conjugam-se critérios das teorias de Roxin e Welzel (equívoco semelhante ao cometido pela doutrina). ${ }^{52}$

51 ALFLEN, Pablo Rodrigo. Teoria do domínio do fato. p. 7374 e 88: "Para determinar a autoria nos crimes dolosos, Welzel parte da crítica ao critério adotado pelo Tribunal do Reich alemão à época - e amplamente difundido por Kohlrausch e Lange -, a saber, o critério da vontade de autor (Täterwillen), ou seja, da vontade de cometer o fato como próprio"; veja-se, ainda, WELZEL, Hans. Studien zum System des Strafrechts. p. 163.

52 Tal questão também foi colocada, recentemente, por HAAS, Volker. Die Theorie der Tatherrschaft und ihre Grundlagen. p. 23: "existem critérios para determinar qual medida de domínio do fato deve ser alcançada para legitimar a responsabilidade penal como autor?".

\subsection{A jurisprudência}

Um exame mais detido de alguns casos extraídos da jurisprudência brasileira permite observar claramente as dificuldades encontradas, no que diz respeito à aplicação da teoria do domínio do fato aos casos concretos submetidos à apreciação do aparato jurisdicional ${ }^{53}$. Aliás, permite concluir que os déficits evidenciados ao longo da decisão proferida pelo Supremo Tribunal Federal no famigerado "caso mensalão", não são nada mais do que o nítido reflexo dos equívocos há muito cometidos pela doutrina e jurisprudência brasileiras.

\subsubsection{Homicídio qualificado e ocultação de cadáver}

Ao julgar Recurso de Apelação Criminal interposto contra decisão condenatória de primeiro grau, o Tribunal de Justiça do Estado de Alagoas utilizou o domínio do fato para fundamentar a coautoria em hipótese de crime de homicídio qualificado. No caso, os policiais " $E$ ” e "N" abordaram “B”. Na ocasião da abordagem, o policial "E” efetuou um disparo na direção de “B” para assustá-lo, o qual, no entanto, restou atingido. Temendo levá-lo ao hospital local por serem muito conhecidos, os policiais decidiram levá-lo a um hospital vizinho. Contudo, no trajeto, enquanto " $N$ " dirigia o veículo, "E” efetuou vários outros disparos contra "B", que causaram a sua morte. Em virtude disso, "E" e "N" "desovaram" o corpo de "B" em um matagal à beira da estrada. Ambos restaram denunciados e condenados pela prática dos crimes tipificados nos arts. 121, §2., II e 211, combinados com o art. 29, do CP, em coautoria. No recurso interposto por "N", o Tribunal entendeu que "o só fato de não ter ele puxado o gatilho não afasta, em absoluto, a co-autoria", visto que "participou da esdrúxula decisão de levar a vítima", "contribuindo decisivamente para o desfecho do delito, porquanto tinha o poder (domínio) de sustar a evolução criminosa a qualquer instante, mas assim não o fez e com tudo aquiesceu" ${ }^{54}$.

53 Os casos que seguem foram extraídos de uma pesquisa realizada no período de 2006 a 2009, na Universidade Luterana do Brasil, a qual consistiu no exame de mais de 1700 acórdãos coletados junto aos 27 tribunais estaduais estaduais e 05 federais brasileiros, com o objetivo de analisar se a teoria do domínio do fato era utilizada e quais os critérios eram empregados nas decisões para fundamentar a autoria direta, a autoria mediata e a coautoria à luz da teoria do domínio do fato; para maiores detalhes sobre a jurisprudência compare ALFLEN, Pablo Rodrigo. Teoria do domínio do fato. p. 170 e ss.

54 TJAL, Apelação Criminal n. ${ }^{\circ}$ 1999.001465-7, Câmara criminal, Rel. Des. José Fernando Lima Souza, Julgada em 24/04/2003. 
Em tal situação o Tribunal aplicou parcialmente a concepção de domínio final do fato de Welzel, pois levou em conta o critério da "decisão comum" em relação ao resultado perpetrado por " $E$ " e "N", (seja porque decidiram conjuntamente levar ao hospital vizinho, seja porque, após, conjuntamente desovaram o corpo em matagal), bem como o critério da "execução comum", ao ressaltar que, embora não tenha acionado o gatilho da arma da fogo (ato executório), "N" realizou atos de apoio, os quais permitiam caracterizá-lo como codetentor da decisão conjunta do fato. Todavia, o critério do "poder de sustar a evolução criminosa", utilizado pelo Tribunal, não coaduna com a ideia de domínio final do fato, mas sim com a concepção desenvolvida por Maurach, no sentido de "deter nas mãos o curso do acontecimento típico", que se traduz pelo "deixar prosseguir, impedir ou interromper" a realização típica ${ }^{55}$. Além disso, a ideia de "contribuição decisiva para o desfecho do delito" coaduna com a ideia de "contribuição essencial à etapa de execução" ou de pressuposto imprescindível ("unerläßliche Voraussetzung"), criada por Roxin ${ }^{56}$. Logo, há uma conjugação de critérios, que não permitem dizer se o tribunal adotou especificamente uma ou outra concepção. Ademais, mesmo que tais critérios fossem empregados de forma uníssona e coerente, isto é, adotando-se uma única concepção teórica, seria imprescindível esclarecer por que tal contribuição era decisiva, bem como se o poder se "sustar a evolução criminosa" exisita em relação ao crime de homicídio ou de ocultação de cadáver, ou, ainda, a ambos.

\subsubsection{Roubo majorado}

O Tribunal de Justiça do Estado de Alagoas também utilizou o domínio do fato para fundamentar a coautoria na hipótese de crime de roubo. No caso, após ingerir bebida alcoólica, "C" e "J" dirigem-se a um ponto de táxi da cidade e solicitam à " $V$ ", taxista, que os leve a determinado local. Lá chegando, com o intuito de roubar o automóvel, "J" aponta uma arma de fogo para a cabeça de "V", enquanto " $\mathrm{C}$ " investe contra este com uma faca, ferindo-o no pescoço. Logo após, fogem com o automóvel para a cidade vizinha, onde são presos. "C" e "I" são denunciados e

$55 \quad$ MAURACH, Reinhard. Deutsches Strafrecht, p. 504: "das vom Vorsatz umfaßte In-Händen-Halten des tatbestandsmäßigen Geschehensablaufes".

56 Cfe. ALFLEN, Pablo Rodrigo. Teoria do domínio do fato. p. 120 e 122; bem como ROXIN, Claus. Täterschaft und Tatherrschaft. p. 280. condenados pela prática do crime tipificado no art. 157, $\S$ 2. ${ }^{\circ}$, I e II do CP, em coautoria. O Tribunal entendeu ser "autor do delito todo aquele que possui poder de decisão sobre a realização do fato, decidindo acerca da prática (se realiza) e da forma desta (como realizar)", bem como que "para ser configurada a co-autoria, não se faz necessária a exata concretização por parte dos agentes da hipótese normativa, bastando que exista a divisão das tarefas para atingir a finalidade vedada pelo sistema legal". No caso, "C" "não tinha o controle do carro quando da fuga, nem foi ele que determinou à vitima parar o automóvel", porém, o fato de ter "utilizado uma faca, colocando-a no pescoço da vítima e causando-lhe ferimento, evidencia que sua participação foi decisiva para a consumação do delito".57

$\mathrm{Na}$ presente situação, o Tribunal se equivocou quanto aos critérios welzelianos do domínio final do fato, pois utilizou o critério próprio da autoria direta, a saber "o poder de decisão sobre a realização do fato", para delimitação da coautoria. Para Welzel, o coautor não possui o poder de decisão sobre a realização do fato integral, mas o poder de decisão sobre a sua parcela de contribuição, daí dizer que a coautoria assenta na "decisão comum" e na divisão de papéis. Ademais, o critério da "participação decisiva” não integra a concepção de domínio final do fato, mas sim a concepção de Roxin, como o terceiro elemento delineado pelo jurista alemão para caracterização da coautoria, a saber, a "relevância da contribuição". O Tribunal, inclusive, não esclarece o porquê de a contribuição de "C" ser considerada "decisiva" face à conduta de "J", visto que "C" atuou com uma faca, quando a vítima já estava sob a mira da arma de fogo de "J". Mesmo se se levasse em conta este último critério, para fins de coautoria, deveria ser demonstrada a imprescindibilidade da contribuição de " $\mathrm{C}$ ".

\subsubsection{Furto qualificado}

O Tribunal de Justiça do Distrito Federal, seguindo no mesmo sentido, utilizou o domínio do fato para fundamentar a coautoria em crimes patrimoniais, como no caso a seguir: "J" aproximou-se do veículo VW pertencente a "L", arrombou a porta e ingressou no seu interior, do qual subtraiu o aparelho de som automotivo. Com a res furtiva em mãos, "J" fugiu do local em um carro conduzido por "F", que o aguardava. Em razão disso, "J" e "F" foram denunciados

TJAL, Apel. Crim. n. ${ }^{\circ}$ 1998.000387-3, Câmara Criminal, Rel. Des. José Fernando Lima Souza, Julgada em 10/04/2003. 
e condenados pela prática do crime tipificado no art. 155 , $\S 4$. $^{\circ}, \mathrm{IV}$ do CP. Em recurso interposto por "F", para fundamentar a coautoria, o Tribunal afirmou que "vem ganhando primazia nos tribunais a teoria do domínio do fato, idealizada por Claus Roxin, que considera também co-autor o agente que participa de um plano adredemente preparado, com divisão de tarefas, influindo, decisivamente, com a sua conduta, no resultado final do ilícito", e esclareceu que "há relevância causal significativa, quando o réu fica na situação de garante e na posição de quem se presta não só a levar o outro agente à cena do crime, mas também a de lhe permitir, com a fuga, a consumação e o próprio exaurimento do crime"s8.

No caso, o Tribunal, aplicando a teoria do domínio do fato de Roxin, especificou tanto o planejamento conjunto baseado na divisão de tarefas - o qual se verifica pela atribuição da tarefa de assegurar a fuga, a "F" - quanto a realização conjunta, observando-se que, segundo Roxin, não é necessário "que as contribuições dos diversos coautores devam ser realizadas ao mesmo tempo", nem mesmo é necessária "a presença no lugar da realização do resultado". ${ }^{59}$ Porém, em relação ao terceiro pressuposto, a saber, "a relevância da contribuição", não foi suficientemente esclarecido se a conduta de "F" consistiu em um "pressuposto imprescindível" ("unerläßliche Voraussetzung"), no sentido de Roxin; e isso é decisivo para fins de caracterização da coautoria, pois, do contrário, estar-se-ia diante de uma hipótese de participação.

\subsubsection{Roubo majorado}

Ao julgar Recurso de Apelação Criminal interposto contra decisão condenatória de primeiro grau, o Tribunal de Justiça do Distrito Federal aplicou a teoria do domínio do fato, novamente, com o propósito de fundamentar a coautoria, ao seguinte caso: " $M$ ", "V" e " $R$ " subtraíram, mediante ameaça com emprego de arma de fogo, R\$ 7.000,00 e cheques da empresa "L". Na ocasião, "V", com o emprego de arma da fogo, intimidou as funcionárias "S" e "I", enquanto "M" recolhia os valores. A participação de " $R$ ", que era funcionário da empresa, consistiu em informar a "M" e "V" o horário mais adequado para a prática do crime, em aguardar a chegada dos comparsas ao local simulando estar trabalhando e em indicar a localização do escritório onde os valores estavam guardados.

58 TJDF, Apel. Crim. $n .^{\circ} 20020110414487,1^{\text {a }}$ Turma Criminal, Rel. Des. Edson Alfredo Smaniotto, Julgada em 30/10/2006. ROXIN, Claus. Strafrecht, AT. Bd. II. p. 82.
Com isso, "M", "V" e "R" foram condenados pela prática do crime tipificado no art. $157, \S 2 .^{\circ}$, I e II, combinado com o art. 29 do CP, na qualidade de coautores. O Tribunal entendeu que " $M$ " "atuou com domínio do fato, dividindo tarefas com seu comparsa, pois pouco importa se somente este portava arma de fogo", inclusive, entendeu que apesar da "pluralidade de condutas", "todas se revestiram de relevância causal e se enquadraram diretamente no tipo descrito na denúncia"60.

Na hipótese, o Tribunal utilizou a ideia de domínio do fato, de Roxin, para fundamentar a coautoria, sendo que restou identificado o planejamento conjunto, sobretudo, em virtude da divisão da tarefas claramente delimitada entre os participantes. Todavia, não foram esclarecidos os pressupostos da execução conjunta e da relevância da contribuição. Em primeiro lugar, Roxin afirma que "somente quem desempenha algum papel na execução pode codominá-la" ${ }^{\prime \prime}$, porém, quem realiza alguma contribuição na etapa da preparação, ainda que ela seja importante, cede a execução a outrem e, por conseguinte, renuncia ao seu domínio. Tal critério não é suficiente para delimitar a coautoria neste caso, pois não se pode afirmar com clareza que "R" também possuía o domínio do fato. Sua participação apresentava muito mais um caráter facilitador. Ademais, foi justamente o déficit resultante deste critério que levou Roxin a desenvolver um terceiro, a saber, a relevância da contribuição. Assim, em segundo lugar, o simples fato de o Tribunal referir que as condutas "se revestiram de relevância causal" não é suficiente, pois, de acordo com a teoria de Roxin, esta relevância radica na imprescindibilidade da contribuição, e, no caso, ter-se-ia que indagar se o fato não teria se concretizado sem a contribuição de "R". Por fim, o Tribunal afirmou que todas as condutas "se enquadraram diretamente no tipo", mas, quanto a isso, deve-se fazer duas considerações: a primeira radica no fato de que este critério não integra a

60 TJDF, Apel. Crim. n. ${ }^{\circ} 20000610044842,1^{\text {a }}$ Turma Criminal, Rel. Des. Ana Maria Duarte Amarante, Julgada em 29/11/2001.

61 ROXIN, Claus. Strafrecht, AT. Bd. II. p. 82, quanto a isso Roxin ressalta, ainda, que sua concepção está em absoluta oposição ao entendimento jurisprudencial, visto que tanto o RG quanto o BGH fixaram o entendimento de que é suficiente para caracterizar a coautoria uma colaboração mínima na etapa da preparação; compare, ainda, ROXIN, Claus. Täterschaft und Tatherrschaft. p. 657; no mesmo sentido PUPPE, Ingeborg. Der gemeinsame Tatplan der Mittäter. ZIS, nº6, 2007. p. 241: "O coautor deve realizar sua contribuição para o fato na etapa da execução". 
concepção de Roxin, e, a segunda, no fato de que a conduta de " $R$ " não se enquadra no tipo penal referido (art. $157, \S 2 .^{\circ}$, I e II do CP), de modo que não haveria que se falar em coautoria em relação a " $R$ ".

\subsubsection{Síntese conclusiva}

Os casos acima citados de forma meramente ilustrativa permitem concluir que não há unissonância em relação aos critérios utilizados pelos tribunais, o que, inclusive, é uma decorrência da falta de percepção acerca da incompatibilidade teórica das vertentes existentes. Inclusive, dentre os mais variados critérios utilizados pela jurisprudência para a determinação da autoria, pode-se mencionar, também, a modo de síntese, a decisão conjunta $^{62}$, a divisão de tarefas ${ }^{63}$, o poder de decidir sobre o "se" e o "como" realizar o fato e de interrompê-lo $0^{64}$, a desnecessidade da prática da conduta executória descrita no tipo ${ }^{65}$, a realização conjunta da conduta criminosa $a^{66}$, a con-

62 Nesse sentido, compare também TJRJ, Apel. Crim. n. ${ }^{\circ}$ 2005.050.04643, $1^{\text {a } C a ̂ m a r a ~ C r i m i n a l, ~ R e l . ~ D e s . ~ M a r c u s ~ B a-~}$ silio, Julgada em 27/12/2005.

63 Nesse sentido, compare também TJGO, Apel. Crim. n. ${ }^{\circ}$ 19820-0/213, 1a Câmara Criminal, Rel. Des. Paulo Teles, Julgada em 25/04/2000; bem como a decisão do TJES, Apel. Crim. $n .^{\circ}$ 023.04.000188-7, 2 ${ }^{\text {a }}$ Câmara Criminal, Rel. Des. Manoel Alves Rabelo, Julgada em 30/11/2005; e, do mesmo modo, TJDF, Apel. Crim. $n .^{o} 20030110018160,1^{\text {a }}$ Câmara Criminal, Rel. Des. Edson Alfredo Smaniotto, Julgada em 02/06/2005; assim como o TJDF, Apel. Crim. n. ${ }^{\circ}$ 20020110414487, $1^{\text {a }}$ Turma Criminal, Rel. Des. Edson Alfredo Smaniotto, Julgada em 30/10/2006; ainda TJPR, Apel. Crim. n. ${ }^{\circ}$ 0262992-3, $3^{\text {a }}$ Câmara Criminal, Rel. Des. Rogério Kanayama, Julgada em 16/06/2005.

64 Nesse sentido também TJMT, Apel. Crim. n. ${ }^{\circ}$ 19153/2005, $3^{\text {a }}$ Câmara Criminal, Rel. Des. Pedro Sakamoto, Julgada em $15 / 08 / 2005$.

65 Nesse sentido TJMS, Apel. Crim. n. ${ }^{\circ}$ 2006.002348-4, $2^{\text {a }}$ Turma Criminal, Rel. Des. José Augusto de Souza, Julgada em 19/04/2006; bem como TJMG, Apel. Crim. n 1.0701.05.109770-0/001, 5 ${ }^{\text {a }}$ Câmara Criminal, Rel. Des. Hélcio Valentim, Julgada em 25/04/2006; igualmente TJRS, Apel. Crim. n. ${ }^{\circ} 70003039930,8^{\text {a }}$ Câmara Criminal, Rel. Des. Roque Miguel Fank, Julgado em 20/02/2002. Também STJ, REsp 1.068.452, Rel. Min. Arnaldo Esteves Lima, Julgado em 02/06/2009: “aplicável a teoria do domínio do fato para a delimitação entre coautoria e participação, sendo coautor aquele que presta contribuição independente, essencial à prática do delito, não obrigatoriamente em sua execução"; bem como STJ, HC 191.444, Rel. Min. Og Fernandes, Julgado em 06/09/2011: "a autoria pode se revelar de diversas maneiras, não se restringindo à prática do verbo contido no tipo penal".

66 Nesse sentido TJRS, Apel. Crim. n. ${ }^{\circ} 70039361084,6^{\mathrm{a}}$ Câmara Criminal, Rel. Des. Cláudio Baldino Maciel, Julgada em $16 / 12 / 2010$. tribuição decisiva ${ }^{67}$ ou relevante ${ }^{68}$ para o resultado e o prévio ajuste. Portanto, os déficits decorrentes da inexistência de coesão e uniformidade nos critérios utilizados são evidentes e permitem concluir que não há uma concepção predominante e muito menos que a jurisprudência se dispôs, deliberadamente, a construir uma nova vertente.

\subsection{APn 470 do STF: o "caso mensalão"}

Conforme foi possível verificar até aqui, os equívocos praticados pela jurisprudência brasileira, no que diz respeito ao emprego da teoria do domínio do fato para fins de delimitação da autoria, são evidentes, a ponto de não se poder afirmar se há uma concepção predominante, quais os critérios realmente adotados ou, inclusive, se a jurisprudência se dispôs, deliberamente, a construir uma nova vertente (o que não parece ser o caso, devido à falta de uniformidade e coesão verificada entre as decisões). Logo, como referido inicialmente, o julgamento do famigerado "caso mensalão" não destoaria da confusa práxis jurisdicional brasileira até então evidenciada. Porém, devido à relevância, à complexidade e à repercussão nacional e estrangeira do caso é importante analisar de forma mais detida alguns aspectos da decisão proferida, mais especificamente, aqueles atinentes à chamada teoria do domínio do fato.

Pois bem, em 20 de julho de 2005 foi instaurado Inquérito perante o Supremo Tribunal Federal, para apurar esquema de corrupção e desvio de dinheiro público, caracterizado pelo pagamento mensal de propinas a membros do Congresso Nacional em troca de apoio ao governo federal, envolvendo tanto membros da cúpula do governo quanto parlamentares. Com base na investigação realizada, o Ministério Público Federal promoveu a acusação de 40 (quarenta) indivíduos em razão da prática dos crimes de quadrilha ou bando (art. 288, do $\mathrm{CP}$ ), peculato (art. 312, do CP), corrupção passiva (art. 317, do CP), corrupção ativa (art. 333, do CP), lavagem de dinheiro (Art. 1º, V, VI e VII, da Lei n. ${ }^{\circ}$ 9.613/1998), gestão fraudulenta de instituição financeira e evasão de divisas (respectivamente, art. $4^{\circ}$ e art. 22, parágrafo único,

67 TJMG, Apel. Crim. n. ${ }^{\circ}$ 1.0460.05.017607-8/001, 5a Câmara Criminal, Rel. Des. Hélcio Valentim, Julgada em 17/04/2007.

68 Nesse sentido TJMG, Apel. Crim. n. ${ }^{\circ}$ 1.0261.04.0271239/001, 5a Câmara Criminal, Rel. Des. Alexandre Victor de Carvalho, Julgada em 17/10/2006. 
da Lei n. $\left.{ }^{\circ} 7.492 / 1986\right) .{ }^{69} \mathrm{Tal}$ acusação foi recebida em 28 de agosto de 2007, pelo Supremo Tribunal Federal, e, por conseguinte, culminou na APn $470 .^{70}$

Por ocasião do julgamento da referida ação penal, na tentativa (e no afã) de proceder à delimitação da autoria dos acusados, o Supremo Tribunal Federal utilizou de uma anomalia, a qual intitulou de "teoria do domínio do fato". De forma absolutamente incongruente, ao longo de mais de oito mil páginas que integram o acórdão, a Corte fundiu teorias incompatíveis entre si, não especificou os critérios que utilizou para nortear aquilo que denominou de "domínio do fato", e, sobretudo, deixou de indicar analiticamente dados empíricos hábeis a fundamentar o suposto domínio do fato enfatizado na decisão. De maneira surpreendente, a Corte tentou, inclusive, proceder a um retrospecto histórico sintético da teoria do domínio do fato, sem sequer chegar ao seu conteúdo (o qual, no entanto, deveria ter sido o principal aspecto a ser discutido). Na decisão restou demonstrado de forma clara, que a "teoria" foi utilizada como simples retórica para fins de atribuição de responsabilidade.

Descabe proceder a um exame minucioso e analítico do acórdão em sua integralidade, sobretudo, em virtude da sua dimensão estratosférica, de modo que é suficiente, para os fins deste estudo, analisar as principais passagens em que se faz menção à teoria do domínio do fato. Como primeiro aspecto a ser analisado, pode-se apontar a afirmação de que "a teoria do domínio fato constitui uma decorrência da teoria finalista de Hans Welzel" ${ }^{71}$. Tal assertiva é equivocada e incoerente, por duas razões:

a) em primeiro lugar, tal afirmação não pode ser utilizada em relação à "teoria do domínio do fato" de modo geral, mas tão só em relação à teoria do domínio final do fato, conforme originariamente desenvolvida por Welzel. Isso, porque a teoria elaborada por Roxin não é

69 Cfe. Peça acusatória (denúncia) disponível no site «http:// noticias.pgr.mpf.mp.br/noticias/noticias-do-site/copy_of_ pdfs/INQ\%202245\%20-\%20denuncia\%20 mensalao.pdf/ view».

70 BRASIL. Supremo Tribunal Federal. Tribunal Pleno, APn 470/MG, Julgado em 17 de dezembro de 2012, p. 1061. Disponível em «http://www.stf.jus.br/portal/ inteiroTeor/ obterInteiroTeor.asp?idDocumento=3678648».

71 BRASIL. Supremo Tribunal Federal. Tribunal Pleno, APn 470/MG, Julgado em 17de dezembro de 2012, p. 1161, disponível em «http://www.stf.jus.br/portal/ inteiroTeor/obterInteiroTeor.asp?idDocumento=3678648». decorrência da teoria finalista, ao contrário, foi desenvolvida justamente a partir do rechaço absoluto à concepção de domínio final do fato, de Welzel $^{72}$;

b) em segundo lugar, ao longo da decisão há referência constante à concepção de Roxin e às formas de domínio do fato por ele desenvolvidas e denominadas (principalmente, o chamado "domínio funcional”), de modo que, evidentemente, a decisão procurou encontrar amparo muito mais na concepção de Roxin do que na de Welzel. Logo, deveria ter sido levada em conta a estrutura dogmática delineada por Roxin e, com isso, observado que a mesma não coaduna com o sistema de Welzel.

Um exame mais acurado, inclusive, permite observar que a Corte aderiu, de forma expressa, à concepção delineada por Roxin, conforme se verifica a partir do seguinte excerto da decisão:

Com efeito, a moderna dogmática jurídico-penal apregoa que os coautores são aqueles que, possuindo domínio funcional do fato, desempenham uma participação importante e necessária ao cometimento do ilícito penal. Nas palavras de Claus Roxin, principal artífice desta teoria do domínio funcional do fato:

se pone de manifiesto que entre las dos regiones periféricas del dominio de la acción y de la voluntad, que atienden unilateralmente sólo al hacer exterior o al efecto psíquico, se extiende um amplio espacio de actividad delictiva, dentro del cual el agente no tiene ni otra classe de dominio y sin embargo cabe plantear su autoria, esto es, los supuestos de participación activa em la realización del delito em los que la acción típica la lleva a cabo outro.

Todavia, a incongruência da decisão como um todo é manifesta, pois, apesar de haver inúmeras referências em seu teor, no sentido de se adotar a teoria de Roxin, encontram-se várias passagens nas quais, ao tentar fundamentar a autoria com base no domínio do fato, procede-se a um mixtum compositum entre a concepção de Welzel e a forma de domínio do fato em virtude de aparatos organizados de poder ("Organisationsherrschaft"), de Roxin $^{73}$, in verbis:

ROXIN, Claus. Täterschaft und Tatherrschaft. p. 109.

73 Cfe. ALFLEN, Pablo Rodrigo. Teoria do domínio do fato. p. 136 e ss.; compare, ainda, ROXIN, Claus. Straftaten im Rahmen organisatorischer Machtapparate. p.193. 
J. D. detinha o domínio final dos fatos. Em razão do cargo elevadíssimo que exercia à época dos fatos, o acusado J. D. atuava em reuniões fechadas, jantares, encontros secretos, executando os atos de comando, direção, controle e garantia do sucesso do esquema criminoso, executado mediante divisão de tarefas em que as funções de cada corréu encontrava nítida definição." ${ }^{74}$

A afirmação de que um determinado indivíduo "detinha o domínio final dos fatos" supõe uma tomada de posição pela concepção welzeliana, a qual é absolutamente incompatível com a ideia de domínio do fato pelo domínio da vontade em virtude de aparatos organizados de poder (domínio por organização), sendo que a ideia de "cargo elevadíssimo", igualmente citada na decisão, é utilizada claramente no sentido referido por Bloy, "de que uma conduta coordenada verticalmente em regra aponte em direção à autoria mediata" 75 , cujo argumento foi desenvolvido com a finalidade de fundamentar a teoria do domínio por organização, de Roxin. Ademais, a fundamentação no sentido de que o acusado executava "atos de comando, direção, controle e garantia do sucesso do esquema criminoso" se aproxima da concepção de Bottke, do domínio da realização (Gestaltungsherrschaft) desde uma posição relevante, em vez de domínio da vontade, o qual afirma existir autoria mediata quando "dentro de um aparato organizado de poder, com atitude criminógena global, como detentor de posição superior, dá instrução a um subordinado para cometer um crime que, devido à atitude criminosa do coletivo, já estabelecida, ao poder de mando e à disposição, muito provavelmente pode contar com o seu cumprimento"76.

O caráter teratológico da decisão - decorrente da mais absoluta falta de percepção das diferenças terminológicas e, sobretudo, teórico-dogmáticas - é acentuado pelo fato de o Supremo Tribunal Federal utilizar como referen-

74 BRASIL. Supremo Tribunal Federal. Tribunal Pleno, APn 470/MG, Julgado em 17 de dezembro de 2012, p. 4673, disponível em «http://www.stf.jus.br/ portal/inteiroTeor/ obterInteiroTeor.asp?idDocumento=3678648».

75 AMBOS, Kai. Direito Penal: fins da pena, concurso de pessoas, antijuridicidade e outros aspectos. Tradução e comentários de Pablo Rodrigo Alflen. Porto Alegre: Fabris Editor, 2006. p. 51.

76 BOTTKE, Wilfried. Täterschaft und Gestaltungsherrschaft: zur Struktur von Täterschaft bei akiver Begehung und Unterlassung als Baustein eines gemeineuropäischen Strafrechtssystems. München: Müller Verlag, 1992. p. 71 e s.; compare também SCHILD, Wolfgang. Tatherrschaftslehren, p. 42 e ss.; ademais AMBOS, Kai. Direito Penal: fins da pena, concurso de pessoas, antijuridicidade e outros aspectos. p. 52 . cial teórico para a teoria do domínio do fato, que afirma ter adotado (de Roxin), a obra de autores brasileiros declaradamente finalistas, os quais, inclusive, como já demonstrado supra, elaboram um mixtum compositum das teorias existentes (Greco, Cirino dos Santos, Batista e Régis Prado). Em outras palavras, a decisão é embasada em doutrina brasileira orientada pela concepção welzeliana, mas, com isso, procura fundamentar a teoria a partir dos critérios desenvolvidos por Roxin (o que constitui uma contradictio in adjecto). Pode-se observar, por exemplo, que a Corte fundamenta a decisão, ainda, na doutrina de Cezar Bitencourt, o qual segue expressamente a concepção de Welzel e sequer faz referência, em sua obra, à teoria do domínio do fato de Roxin. Assim, refere a Corte:

"Ensina, ainda, CÉZAR ROBERTO BITENCOURT:

\section{‘5.3. Teoria do domínio do fato}

[...] Autor, segundo esta teoria, é quem tem o poder de decisão sobre a realização do fato. É não só o que executa a ação típica como também aquele que se utiliza de outrem, como instrumento, para a execução da infração penal (autoria mediata).

\section{$[\ldots]$}

'A teoria do domínio do fato tem as seguintes consequências: $1^{\text {a }}$ ) a realização pessoal e plenamente responsável de todos os elementos do tipo fundamentam sempre a autoria; $2^{\mathrm{a}}$ ) é autor quem executa o fato utilizando outrem como instrumento (autoria mediata); $3^{\text {a }}$ ) é autor o coautor que realiza uma parte necessária do plano global ("domínio funcional do fato"), embora não seja um ato típico, desde que integre a resolução delitiva comum."' ${ }^{77}$

Todavia, observa-se que, apesar de não fazer referência à Roxin, o jurista brasileiro menciona a forma de domínio funcional por este último criada, cometendo, assim, o mesmo equívoco de Greco, Cirino dos Santos, Régis Prado, Galvão e Mayrink.

Ademais, para fundamentar a responsabilidade penal dos acusados, a Corte utilizou de entendimento obsoleto, que se orienta por critério absolutamente inaceitável. ${ }^{78}$ Trata-se do critério da presunção de participa-

BRASIL. Supremo Tribunal Federal. Tribunal Pleno, APn 470/MG, Julgado em 17 de dezembro de 2012, p. 4703, disponível em «http://www.stf.jus.br/portal/ inteiroTeor/ obterInteiroTeor.asp?idDocumento=3678648».

78 BRASIL. Tribunal Regional Federal da 4. ${ }^{a}$ Região, Habeas Corpus n. ${ }^{\circ}$ 5011346-88.2012.404.0000, Sétima Turma, Rel. Des. Fed. Élcio Pinheiro de Castro, Julgado em 17de julho de 2012: "Nos delitos empresariais, a presunção de autoria 
ção, o qual conduz à responsabilidade penal objetiva dos acusados $^{79}$ e que a Corte utilizou sob o argumento de que aquele que integra o quadro social da empresa, na condição de gestor ou administrador, tem o domínio do fato e, por conseguinte, é autor; vejamos:

Presumidamente, aos detentores do controle das atividades do Banco Rural, conforme dispõe $o$ ato institucional da pessoa jurídica, há de se imputar a decisão (ação final) do crime. Nessa ação coletiva dos dirigentes é interessante a lição de CLAUS ROXIN sobre a configuração do domínio do fato[... $]^{80}$

Este critério - frise-se, atualmente superado - foi estabelecido há muito tempo pela jurisprudência brasileira, a partir de uma interpretação inadequada do art. 25 da Lei n. ${ }^{\circ} 7.492 / 1986$ e do art. 11, da Lei n. ${ }^{\circ}$ $8.137 / 1990$, e, portanto, deve ser rechaçado ${ }^{81}$, pois o domínio do fato deve ser aferido materialmente e não com base em presunção. Além disso, em um Estado Democrático de Direito não se pode conceber a atribuição de responsabilidade a gestores se não foi averiguado e devidamente comprovado o exercício efetivo dos poderes de gestão que lhes eram atribuídos (inclusive, tal aspecto é rechaçado pela própria legislação vigente ${ }^{82}$ ). Aliás,

daqueles que são legalmente investidos na administração da pessoa jurídica é decorrência do exercício, de fato ou de direito (domínio do fato ou da organização), dos atos de gestão, notadamente o adimplemento das obrigações tributárias".

79 ALFLEN, Pablo Rodrigo. Teoria do domínio do fato. p. 179 e ss.; bem como SILVA, Paulo Cezar. Crimes contra o Sistema Financeiro Nacional. São Paulo: Quartier Latin, 2006. p. 79.

80 BRASIL. Supremo Tribunal Federal. Tribunal Pleno, APn 470/MG, Julgado em 17 de dezembro de 2012, p. 1162, disponível em «http://www.stf.jus.br/portal/ inteiroTeor/ obterInteiroTeor.asp?idDocumento=3678648».

81 OLIVEIRA, Antônio Cláudio Mariz. A responsabilidade nos crimes tributários e empresariais. In: ROCHA, Valdir de Oliveira. Direito penal empresarial. São Paulo: Dialética, 1995. p. 29; tal orientação, igualmente rechaçada por Kuhlen, havia sido adotada na Alemanha pelo BGHSt 37, 106 (113f.), compare KUHLEN, Lothar. Strafrechtliche Produkthaftung. In: Sonderducke aus 50 Jahre Bundesgerichtshof. Festgabe aus der Wissenschaft. München: Beck, 2000. p. 663.

82 Os preceitos do CCB impõem a análise dos atos materiais praticados individualmente pelos administradores, para fins de atribuição de responsabilidade. Assim, embora o art. 1.013 disponha que "a administração da sociedade, nada dispondo o contrato social, compete separadamente a cada um dos sócios"; o art. 1.016 determina que "os administradores respondem [...] por culpa no desempenho de suas funções", não se admitindo, portanto, a responsabilidade meramente objetiva pelos atos; isso, inclusive, é como já afirmou Oliveira, "a responsabilidade penal não pode ser ficta, presumida, diversa daquela proveniente da própria conduta do agente e de sua postura psicológica em relação ao evento delituoso" ${ }^{83}$. Portanto, não se pode admitir na ordem jurídica brasileira a presunção de domínio do fato, pois a simples disposição de ato institucional ou contrato social constitutivo de uma organização, indicando quem são gestores, não atribui aos mesmos o efetivo poder de condução do fato delitivo.

De outra sorte, observa-se que a Corte sequer conseguiu situar o domínio do fato na estrutura do conceito analítico de crime, chegando à esdrúxula afirmação de que o domínio do fato consiste em elemento da culpabilidade, ao referir que

[...] o fato de se tratar de empregada e, como tal, de trabalhadora subordinada, e de não dispor de poderes sobre o patrimônio da sociedade empresária não afasta, isoladamente, o domínio do fato delitivo, elemento da culpabilidade ${ }^{84}$.

Trata-se de equívoco inadmissível, sobretudo, em um caso dessa magnitude, pois na dogmática jurídico-penal, a única referência a mencionar o domínio do fato como pressuposto da culpabilidade está em Hegler, o qual, em 1915, afirmou que somente age com culpabilidade quem tem o domínio do fato, porém, o jurista não utilizou a ideia de domínio do fato como critério de delimitação da autoria. ${ }^{85}$

Logo, procedendo à transcrição de passagens doutrinárias absolutamente incompatíveis entre si, a Corte acreditou fundamentar a autoria dos acusados, quando sequer fez referência ao conteúdo da teoria do domínio do fato e aos critérios utilizados para afirmar se e por que alguém detinha o domínio do fato. Isso fica evidenciado, sobretudo, em razão de que, em determinado momento,

corroborado pelo Art. 1.017, o qual dispõe que "o administrador que, sem consentimento escrito dos sócios, aplicar créditos ou bens sociais em proveito próprio ou de terceiros, terá de restituí-los à sociedade, ou pagar o equivalente, com todos os lucros resultantes, e, se houver prejuízo, por ele também responderá".

83 OLIVEIRA, Antônio Cláudio Mariz. A responsabilidade nos crimes tributários e empresariais. p. 29.

84 BRASIL. Supremo Tribunal Federal. Tribunal Pleno, APn 470/MG, Julgado em 17 de dezembro de 2012, p. 1255, Disponível em: «http://www.stf.jus.br/portal/ inteiroTeor/ obterInteiroTeor.asp?idDocumento=3678648».

85 Cfe. SCHROEDER, Fr.-Christian. Der Täter hinter dem Täter. p. 59; bem como ROXIN, Claus. Täterschaft und Tatherrschaft. p. 60; ademais, ALFLEN, Pablo Rodrigo. Teoria do domínio do fato. p. 60. 
orientando-se nitidamente por uma concepção welzeliana, afirma-se que um dos acusados detinha "o domínio final dos fatos" e, logo em seguida, afirma-se que o mesmo acusado detinha "o domínio funcional dos fatos".

Os problemas identificados na decisão se acentuaram pelo fato de a Corte utilizar como referencial teórico-dogmático a obra de Régis Prado, o qual, como já referido, confunde totalmente as concepções de Welzel e Roxin. Para compreender tal afirmação, é suficiente observar o seguinte excerto do acórdão:

É importante destacar, neste ponto, fragmento da lição exposta por Luiz Regis Prado ("Curso de Direito Penal Brasileiro", vol. 1/475-476, item n. 2, 6a ed.2006, RT), na qual, com muita propriedade, enfocou a matéria ora em exame:

‘) Teoria objetiva final, objetiva-subjetiva ou do domínio do fato - de base finalista, conceitua autor como aquele que tem o domínio final do fato (conceito regulativo), enquanto o partícipe carece desse domínio. $\mathrm{O}$ princípio do domínio do fato significa 'tomar nas mãos o decorrer do acontecimento típico compreendido pelo dolo'. Pode ele se expressar em domínio da vontade (autor direto e mediato) e domínio funcional do fato (coautor). Tem-se como autor aquele que domina finalmente a realização do tipo de injusto. Coautor aquele que, de acordo com um plano delitivo, presta contribuição independente, essencial à prática do delito - não obrigatoriamente em sua execução.

A situação somente não seria pior se o citado autor não tivesse cometido o gravíssimo equívoco de atribuir à teoria do "domínio final do fato" (de Welzel) a divisão entre as formas de "domínio da vontade" e "domínio funcional". Welzel jamais fez menção às formas de "domínio da vontade" e "domínio funcional" em sua teoria do domínio final do fato. Logo, vê-se que a própria Corte foi induzida em erro, devido aos graves equívocos cometidos, sobretudo, pela doutrina pátria, pois, embora deva-se a Roxin o mérito de ter elaborado a divisão entre as formas de "domínio da ação", "domínio da vontade" e “domínio funcional" $"$, a doutrina pátria insiste em atribuí-las à Welzel.

86 Cfe. AMBOS, Kai. Direito penal: fins da pena, concurso de pessoas, antijuridicidade e outros aspectos. p. 49: "Roxin distingue três formas de domínio (domínio do fato pela ação, pela vontade e domínio do fato funcional)”.

\section{Incompatibilidade da teoria do domínio do fato com a ordem jurídica brasileira}

Como se não bastassem as incongruências e os equívocos cometidos ao longo da decisão proferida pelo STF na APn 470, no tocante ao emprego da teoria do domínio do fato, maior gravidade apresenta a afirmação da Corte no sentido de que a teoria do domínio do fato, de Roxin, não ofende o ordenamento brasileiro, ao contrário, revela-se "compatível com a disciplina que o nosso Código Penal estabeleceu” e que “a adoção, pela legislação brasileira, da teoria unitária em matéria de concurso de pessoas não afasta a possibilidade de reconhecimento, em nosso sistema jurídico-penal, da teoria

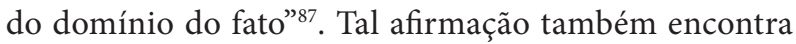
respaldo na doutrina brasileira, pois, Batista, ao analisar a teoria do domínio do fato de Roxin, afirma que "para o direito penal brasileiro, nenhum obstáculo teórico existe contra a utilização desse critério para os crimes comissivos dolosos"88.

Evidentemente, o Código Penal brasileiro de 1940, ao dispor no art. 25 - atual art. 29 - que "quem, de qualquer modo, concorre para o crime incide nas penas a este cominadas" adotou um sistema unitário de autor. ${ }^{89}$ Apesar de o legislador parecer, com isso, estar equiparando todos os participantes do crime à figura de autores, certo é que a parificação legal não tem o condão de fazer desaparecer as diferenças reais que distinguem as várias formas de participação, uma vez que, como já esclareceu Esther Ferraz, "são, todas essas, diferenças reais que a lei pode ignorar sem, contudo, ter forças para eliminar", bem como, porque tal diferenciação é importante "para os efeitos da aplicação da sanção punitiva" ${ }^{\text {"90 }}$. Todavia, a

87 BRASIL. Supremo Tribunal Federal. Tribunal Pleno, APn 470/MG, Julgado em 17 de dezembro de 2012, p. 5199, disponível em «http://www.stf.jus.br/portal/ inteiroTeor/ obterInteiroTeor.asp?idDocumento=3678648».

88 BATISTA, Nilo. Concurso de agentes. p. 73.

89 Cfe. FERRAZ, Esther de Figueiredo. A co-delinquencia no direito penal brasileiro. São Paulo: Bushatsky Editor, 1976. p. 3 e ss.; FRAGOSO, Heleno. Lições de Direito Penal: parte geral. 2. ed. São Paulo: Bushatsky Editor, 1977. p. 312; DOTTI, René Ariel. O concurso de pessoas. Revista da Faculdade de Direito da UFG, Belo Horizonte, n. 5, v. (1-2), p. 74-75, jan./dez. 1981; COSTA JÚNIOR, Paulo José. Curso de direito penal. São Paulo: Saraiva, 1997. v. 1. p. 116; BRUNO, Anibal. Direito Penal: parte geral. 2. ed. Rio de Janeiro: Forense, 1959. v. 1, T.1, p. 261; ALFLEN, Pablo Rodrigo. Teoria do domínio do fato. São Paulo: Saraiva, 2014. p. 165 e s.

90 FERRAZ, Esther de Figueiredo. A co-delinquencia no direito 
opção por um sistema unitário — desenvolvido originariamente em 1828 por Stübel — foi uma consequência inevitável da influência italiana sobre a a doutrina e a legislação brasileira da época. Inclusive, tal opção foi mantida no art. 29 do CP (alterado pela Lei no 7.209/1984), ao dispor que "quem, de qualquer modo, concorre para o crime incide nas penas a este cominadas, na medida de sua culpabilidade" 91 .

Embora o legislador brasileiro tenha adotado o sistema unitário, também deixou claro dois aspectos: em primeiro lugar, que o sistema unitário não é incompatível com a distinção entre as modalidades de autoria e participação; e, em segundo lugar, que, apesar de a legislação não definir os conceitos, apresentou alguns critérios, os quais devem nortear a doutrina nessa tarefa. Daí dizer Mestieri ser a referência à culpabilidade, disposta no final do art. 29, uma "cláusula salvatória"92 frente aos excessos a que poderia levar uma interpretação radicalizante orientada por uma concepção parificadora, e que, em virtude disso, o legislador teria adotado uma "teoria unitária temperada"93.

Todavia, cumpre observar que a denominação “teoria unitária temperada”, referida por Mestieri, não consistiu em uma nova teoria, mas uma simples forma de designar uma concepção peculiar, divergente daquela apresentada originariamente por Stübel e adotada em 1940 no Código Penal brasileiro. Isso, evidentemente, deve-se ao fato de que a doutrina brasileira à época da reforma da Parte Geral (1984) desconhecia a tradicional distinção entre sistema unitário formal e sistema unitário funcional, cuja divisão e denominação havia sido elaborada por Diethelm Kienapfel, em $1971^{94}$. Como sistema unitário formal, o jurista denomina o "sistema unitário de autor que admite expressamente como consequência a unificação de todas as formas de cometimento do fato e renuncia às diferenciações conceituais-categoriais no

penal brasileiro. p. 4 e 7; também SEMERARO, Pietro. Concorso di persone nel reato e commisurazione della pena. Padova: Cedam, 1986. p. 91 e ss.

91 ALFLEN, Pablo Rodrigo. Teoria do domínio do fato. p. 165 e s.

92 MESTIERI, João. Teoria Elementar do Direito Criminal: parte geral. Rio de Janeiro: ed. J. Mestieri, 1990. p. 253.

93 MESTIERI, João. Teoria Elementar do Direito Criminal: parte geral. p. 253.

94 KIENAPFEL, Diethelm. Erscheinungsformen der Einheitstäterschaft. In: MÜLLER-DIETZ, Heinz (Hrsg.). Strafrechtsdogmatik und Kriminalpolitik. Köln: 1971, p. 34 e ss.; ALFLEN, Pablo Rodrigo. Teoria do domínio do fato. p. 56 s. e 168 s.; bem como ROTSCH, Thomas. "Einheitstäterschaft" statt Tatherrschaft. p.133. plano da tipicidade". Tal sistema elimina "as diferenças valorativas e existenciais entre as tradicionais formas de autoria e participação”. O sistema unitário funcional, assim "como o formal, renuncia a qualquer divisão valorativa de determinadas forma de cometimento do fato, mas, ao contrário deste, não renuncia à sua diferenciação conceitual"95. Logo, a ordem jurídico-penal brasileira adotou um sistema unitário funcional, e somente neste sentido pode ser entendida a chamada "teoria unitária temperada”.

Esclarecido esse aspecto, cumpre responder à questão se um sistema unitário admite a teoria do domínio do fato. Dois fatores conduzem a uma resposta para essa questão, a saber: em primeiro lugar, Roxin não só rechaça categoricamente a adoção de um sistema unitário ${ }^{96}$, como esclarece que desenvolveu sua teoria (do domínio do fato) sobre o pilar do sistema diferenciador; em segundo lugar, a concepção de domínio do fato (tanto finalista quanto funcionalista-normativista) está assentada no absoluto rechaço a premissas causais-naturalistas, as quais, diferentemente, são o pilar de sustentação do sistema unitário. Por conseguinte, não há como transpor a teoria do domínio do fato ao plano brasileiro, face à sua absoluta incompatibilidade com a ordem jurídica vigente e com a opção do legislador brasileiro por um sistema unitário funcional.

Com isso, verifica-se o total desconhecimento tanto da doutrina brasileira, quanto da jurisprudência, acerca do absoluto rechaço por parte de Roxin ao sistema unitário de autor, o qual foi recepcionado pelo Código Penal brasileiro, e, principalmente, que a teoria do penalista alemão foi criada tendo em vista o sistema diferenciador adotado pelo Código Penal alemão. ${ }^{97}$

\section{Considerações finais}

$\mathrm{O}$ exame realizado até aqui permite concluir que tanto a doutrina quanto a jurisprudência brasileiras há muito cometem graves equívocos e incongruências, no que diz respeito ao tratamento e aplicação da teoria do domínio do fato, de modo que a decisão proferida pelo

95 KIENAPFEL, Diethelm. Erscheinungsformen der Einheitstäterschaft. p. 26-27.

96 ROXIN, Claus. Strafrecht. AT. Bd. 1. p. 5-6: "Com o conceito unitário de autor deve-se rechaçar também o conceito extensivo de autor".

97 ROXIN, Claus. Strafrecht. AT. Bd. 1.p. 5. 
Supremo Tribunal Federal, ao julgar a Ação Penal N 470, não destoaria da confusa práxis jurisdicional brasileira até então evidenciada.

Ademais, a decisão proferida pela Corte nos autos da Ação Penal $N^{\circ} 470$, não adotou a teoria do domínio final do fato, desenvolvida por Welzel, nem a teoria do domínio do fato, desenvolvida por Roxin, mas sim, utilizou uma anomalia resultante da conjugação dos critérios de ambas as concepções, o que conduziu a uma absoluta contradição. Além disso, tal equívoco foi decorrente da própria dificuldade que a doutrina brasileira apresentou (e apresenta) no tocante à compreensão de ambas as concepções e de suas diferenciações, o que, inevitavelmente, se refletiu em uma práxis jurisdicional incongruente e, por ora, em uma decisão absolutante incorreta. Por fim, cabe ter em vista que a teoria do domínio do fato de Roxin não é compatível com a ordem jurídico-penal brasileira, em virtude da opção do legislador brasileiro por um sistema unitário funcional no tocante ao concurso de pessoas. Todavia, isso não implica o rechaço à ideia de domínio do fato, mas a necessidade de construção de uma teoria compatível com a ordem jurídica nacional ${ }^{98}$.

\section{Referências}

ALFLEN, Pablo Rodrigo. Teoria do domínio do fato. São Paulo: Saraiva, 2014.

AMBOS, Kai. Direito Penal: fins da pena, concurso de pessoas, antijuridicidade e outros aspectos. Tradução e comentários de Pablo Rodrigo Alflen. Porto Alegre: Fabris Editor, 2006.

BATISTA, Nilo. Concurso de agentes. 3. ed. Rio de Janeiro: Lumen Juris, 2005.

BITENCOURT, Cezar Roberto. Tratado de Direito Penal: parte geral. 16. ed. São Paulo: Saraiva, 2011.

BOCKELMANN, Paul. Strafrechtliche Untersuchungen. Göttingen: Verlag Otto Schwartz \& Co, 1957.

BOTTKE, Wilfried. Täterschaft und Gestaltungsherrschaft: zur Struktur von Täterschaft bei akiver Begehung und Unterlassung als Baustein eines gemeineuropäischen Strafrechtssystems. München: Verlag Müller, 1992.
BRAMSEN, Joerg; APEL, Simon. Anstiftung oder Täterschaft? "Organisationsherrschaft" in Wirtschaftsunternehmen. ZJS, n. 03, 2008. p. 256-264.

BRANDÃO, Cláudio. Curso de Direito Penal: parte geral. Rio de Janeiro: Forense, p. 271.

BRUNO, Anibal. Direito Penal: parte geral. 2. ed. Rio de Janeiro: Forense, v. 1, tomo I, 1959.

CAllegARI, André Luís. Teoria Geral do Delito. Porto Alegre: Livraria do Advogado, 2005.

CAPEZ, Fernando. Curso de Direito Penal: parte geral. 12. ed. São Paulo: Saraiva, 2008.

COSTA, Álvaro Mayrink. Direito Penal: parte geral. 8. ed. Rio de Janeiro: Forense, 2009.

DOTTI, René Ariel. O concurso de pessoas. Revista da Faculdade de Direito da UFG, Belo Horizonte, v. (1-2), n. 5, p. 77 e ss, jan./dez. 1981.

FERRAZ, Esther de Figueiredo. A co-delinquencia no direito penal brasileiro. São Paulo: Bushatsky Editor, 1976.

FRAGOSO, Heleno. Lições de Direito Penal: parte geral. 2. ed. São Paulo: Bushatsky Editor, 1977.

GALVÃO, Fernando. Direito Penal: parte geral. Rio de Janeiro: Ímpetus, 2004.

GRECO, Rogério. Curso de Direito Penal: parte geral. São Paulo: Ímpetus, 2012.

GRECO, Rogério. Código Penal Comentado. 8. ed. São Paulo: Ímpetus, 2014.

HAAS, Volker. Die Theorie der Tatherrschaft und ihre Grundlagen. Zur Notwendigkeit einer Revision der Beteiligungslehre. 1. Aufl., Berlin: Duncker \& Humblot, 2008.

JESUS, Damásio de. Teoria do domínio do fato no concurso de pessoas. 3. ed. São Paulo: Saraiva, 2002.

KANTOROWICZ, Hermann. Der Strafgesetzentwurf und die Wissenschaft. Monatsschrift für Kriminalpsychologie und Strafrechtsreform, Bd. 7, 1911.

KIENAPFEL, Diethelm. Erscheinungsformen der Einheitstäterschaft. In: MÜLLER-DIETZ, Heinz (Hrsg.). Strafrechtsdogmatik und Kriminalpolitik. Köln: Heymann, 1971. p. 21-58.

KINDHÄUSER, Urs. Strafrecht. AT. 2. Aufl., BadenBaden: Nomos Verlag, 2002. 
KUHLEN, Lothar. Strafrechtliche Produkthaftung. In: SONDERDUCKE aus 50 Jahre Bundesgerichtshof. Festgabe aus der Wissenschaft. München: Beck, 2000.

MAURACH, Reinhard. Strafrecht, Allgemeiner Teil. Karlsruhe: C.F. Müller, 1954.

MESTIERI, João. Teoria Elementar do Direito Criminal: parte geral. Rio de Janeiro: ed. J. Mestieri, 1990.

MIRABETE, Julio Fabbrini. Manual de Direito Penal: parte geral. 21. ed. São Paulo: Atlas, 2004.

OLIVEIRA, Antônio Cláudio Mariz. A responsabilidade nos crimes tributários e empresariais. In: ROCHA, Valdir de Oliveira. Direito penal empresarial. São Paulo: Dialética, 1995.

OTTO, Harro. Grundkurs Strafrecht. Allgemeine Strafrechtslehre. 7. Aufl., Berlin: Walter de Gruyter, 2004.

PRADO, Luiz Régis. Curso de Direito Penal Brasileiro. 9. ed. São Paulo: Revista dos Tribunais, 2010.

PUPPE, Ingeborg. Der gemeinsame Tatplan der Mittäter. ZIS, n. 06, 2007. p. 234-246. Disponível em: «www.zisonline.com». Acesso em: 20 jan. 2012.

REALE JÚNIOR, Miguel. Instituições de Direito Penal: parte geral. Rio de Janeiro: Forense, 2002.

ROTSCH, Thomas. Tatherrschaft kraft Organisationsherrschaft. ZStW, $\mathrm{n}^{\circ} 112$, Heft 3, 2000. p. 518-562.

ROTSCH, Thomas. "Einheitstäterschaft" statt Tatherrschaft. Tübingen: Mohr Siebeck, 2009.

ROXIN, Claus. O domínio por organização como forma independente de autoria mediata, Trad. Pablo Rodrigo Alflen, Panóptica. Law E-Journal, n. 04, 2009. Disponível em «www.panoptica.org». Acesso em: 25 se.t 2014

ROXIN, Claus. Organisationsherrschaft und Tatentschlossenheit. ZIS, n. 07, 2006, p. 293-300.

ROXIN, Claus. Strafrecht, Allgemeiner Teil. Bd. II, München: Beck, 2003.

ROXIN, Claus. Straftaten im Rahmen organisatorischer Machtapparate. GA, 1963.
ROXIN, Claus. Täterschaft und Tatherrschaft. 6. Aufl., Berlin: Walter de Gruyter, 1994.

RÜBENSTAHL, Markus. Die Übertragung der Grudsätze zur Tatherrschaft kraft Organisationsherrschaft auf Unternehmen durch den BGH. HRRS, n. 10, 2003. p. 210-219.

SANTOS, Juarez Cirino. A moderna teoria do fato punível. 3. ed. Curitiba: IPCP/Lumen Juris, 2004.

SANTOS, Juarez Cirino. Direito Penal: parte geral. 2. ed. Curitiba: IPCP/Lumen Juris, 2007.

SCHILD, Wolfgang. Täterschaft als Tatherrschaft. Berlin: Walter de Gruyter, 1994.

SCHILD, Wolfgang. Tatherrschaftslehren. 1. Aufl., Frankfurt a. M.: Peter Lang, 2009.

SCHROEDER, Friedrich-Christian. Der Täter hinter dem Täter. 1. Aufl., Berlin: Duncker \& Humblot, 1965.

SEMERARO, Pietro. Concorso di persone nel reato $e$ commisurazione della pena. Padova: Cedam, 1986.

SILVA, Paulo Cezar. Crimes contra o Sistema Financeiro Nacional. São Paulo: Quartier Latin, 2006.

TAVARES, Juarez. Teoria do injusto penal. 3. ed. Belo Horizonte: Del Rey, 2003.

URBAN, Carolin. Mittelbare Täterschaft kraft Organisationsherrschaft, Eine Studie zu Konzeption und Anwendbarkeit, insbesondere im Hinblick auf Wirtschaftsunternehmen. 1. Aufl., Göttingen: V\&R unipress, 2004.

WELZEL, Hans. Studien zum System des Strafrechts, In: Abhandlungen zum Strafrecht und zur Rechtsphilosophie, Berlin: Walter de Gruyter, 1975. p. 120-184.

WELZEL, Hans. Das Deutsche Strafrecht: Eine systematische Darstellung. 11. Aufl., Berlin: Walter de Gruyter, 1989.

WESSELS, Johannes; BEULKE, Werner. Strafrecht. AT. Die Straftat und ihr Aufbau. 35. Aufl., Heidelberg: C.F.Müller Verlag, 2005. 